\title{
Types and distribution of Quaternary deposits originating from carbonate rock slopes in the Vinodol Valley, Croatia - new insight using airborne LiDAR data
}

Rudarsko-geološko-naftni zbornik

(The Mining-Geology-Petroleum Engineering Bulletin) UDC: 551.3

DOI: 10.17794/rgn.2020.4.6

Original scientific paper

\author{
Petra Jagodnik1; Sanja Bernat Gazibara²; Vedran Jagodnik'; Snježana Mihalić Arbanas ${ }^{2}$ \\ ${ }^{1}$ University of Rijeka, Faculty of Civil Engineering, Croatia, Radmile Matejčić 3, 51000 Rijeka \\ ${ }^{2}$ University of Zagreb, Faculty of Mining, Geology and Petroleum Engineering, Croatia, Pierottijeva 6, 10000 Zagreb
}

\begin{abstract}
The Vinodol Valley, situated in the north-western Adriatic in Croatia, is characterized by complex geological and morphological conditions. Palaeogene flysch deposits form the inner parts of the valley, while the steep valley flanks are composed of Cretaceous and Palaeogene carbonate rocks. Flysch bedrock is mostly covered by diverse Quaternary deposits, among which deposits originating from carbonate rock slopes are abundant. During previous investigations, based on conventional field geological mapping and mostly conducted in the north-western and central parts of the Vinodol Valley, such Quaternary deposits were addressed to the tectonic evolution of the study area and rockfalls, respectively. Therefore, they were generally named as Quaternary rockfall breccias, or Quaternary rockfall deposits. This study presents six types of the Quaternary deposits originating from carbonate rock slopes and their spatial distribution in the whole Vinodol Valley $\left(64.57 \mathrm{~km}^{2}\right)$, which are identified and mapped based on the visual interpretation of 1-m airborne LiDAR (Light Detection and Ranging) Digital Terrain Model (DTM). Lithological materials are classified according to engineering geological principles, and represent engineering formations. New insight into the types, shapes, geometric characteristics and hypsometrical positions of the identified sedimentary bodies indicate that some other gravitational mass movements, and not just rockfalls, played an important role in the formation of the Quaternary deposits originating from the carbonate rock slopes in the Vinodol Valley. This study also presents the potential of the visual interpretation of high-resolution LiDAR DTM for identification and mapping of superficial deposits in study areas characterized by complex geological and morphological conditions.
\end{abstract}

\section{Keywords:}

Quaternary deposits; visual interpretation; LiDAR DTM; fossil landslides; Vinodol Valley

\section{Introduction}

The Vinodol Valley $\left(64.57 \mathrm{~km}^{2}\right)$ is situated in the north-western Adriatic, in Croatia (see Figure 1a). It represents a lower part of the regional geodynamic domain Ilirska Bistrica - Rijeka - Vinodol - Senj stretching in the NW-SE direction (Prelogović et al., 1981), and encompasses the area between the Križišće settlement and the city of Novi Vinodolski (see Figure 1b). The valley is elongated and narrow, characterized by prominently longer north-eastern and shorter southwestern slopes. Three macro geomorphologic zones represent the main parts of the Vinodol Valley (Đomlija et al., 2017). The north-western (NW) part extends from the Križišće to Tribalj settlements (see Figure 1b), with a length of approx. $7 \mathrm{~km}$ and a width ranging from 950 $\mathrm{m}$ to $3.50 \mathrm{~km}$. The central part extends from the Tribalj to Kričina settlements and has a length of approx. 6.5 $\mathrm{km}$, and a maximum width of $4 \mathrm{~km}$. The south-eastern (SE) part of the Vinodol Valley extends from the Kričina

Corresponding author: Petra Jagodnik

petra.jagodnik@gradri.uniri.hr settlement to the city of Novi Vinodolski, and is characterized by an almost uniform width of approx. $2 \mathrm{~km}$. The Vinodol Valley is a populated rural area, with more than 50 small settlements connected by a relatively dense road network. Hypsometrically, the lower slopes are mostly covered by dense forests, with an area of approx. $32 \mathrm{~km}^{2}$ (CEAN, 2008). Slopes along both valley margins are either bare or sparsely vegetated by shrubs. The Dubračina and Suha Ričina rivers are the two main watercourses in the Vinodol Valley (see Figure 1b). The NW and central part of the Vinodol Valley are encompassed by the Dubračina River Basin, while the SE part belongs to the Suha Ričina River Basin (Đomlija et al., 2017).

The Vinodol Valley flanks are composed of Cretaceous limestone and dolomites, and Palaeogene foraminiferal limestone (see Figure 1c). The inner parts and the bottom of the valley are formed of Palaeogene flysch deposits, predominantly composed of alternations of sandstones and marls (Šušnjar et al., 1970). Highly fractured carbonate rock slopes in both valley flanks are separated from the inner flysch slopes by predominantly 


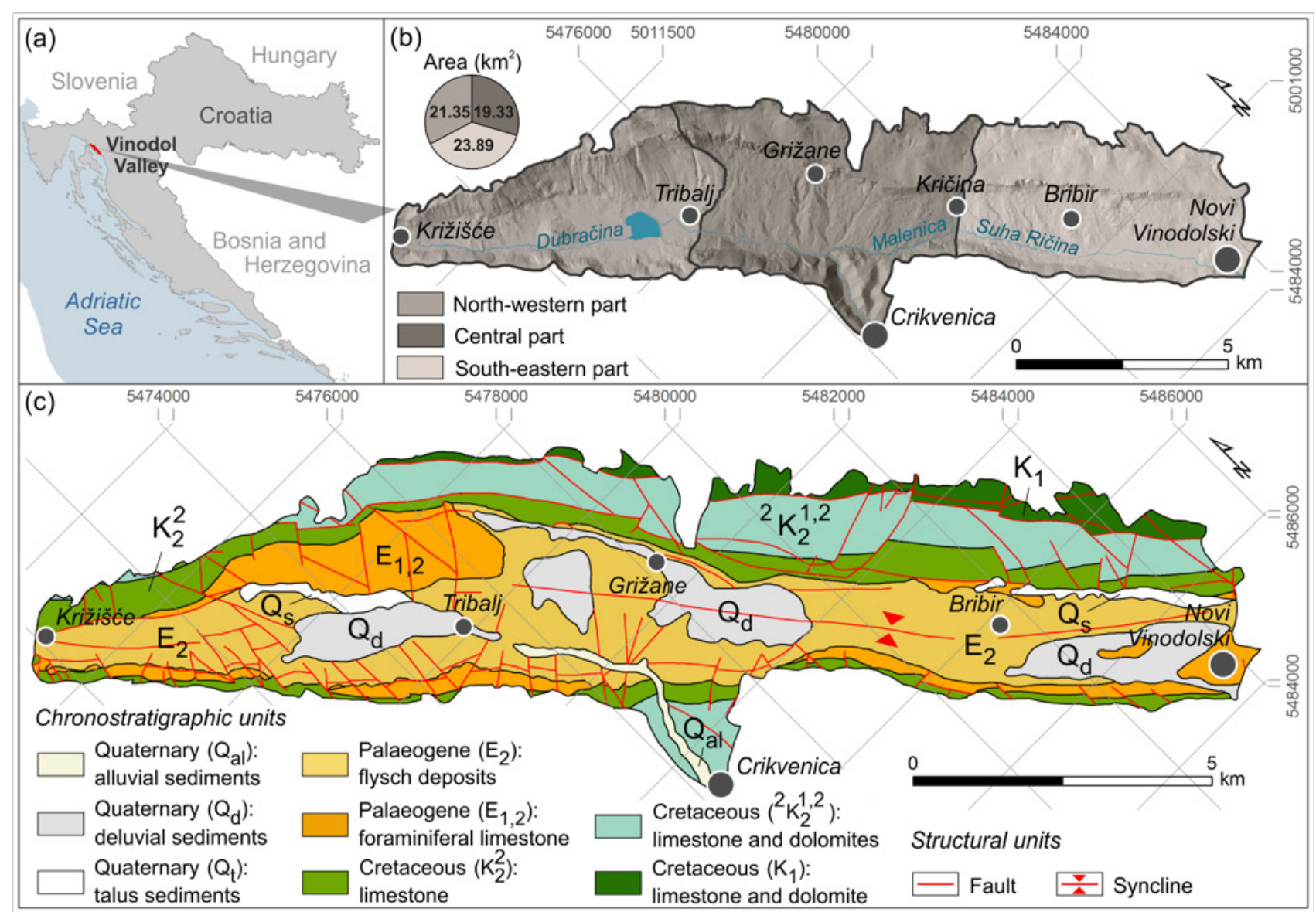

Figure 1: (a) Geographical location of the Vinodol Valley; (b) high resolution shaded LiDAR DTM, with boundaries of three macro geomorphologic zones representing different parts of the Vinodol Valley;

(c) Basic geological map, after Šušnjar et al. (1970).

reverse fault contacts (Blašković, 1999; Palenik et al., 2019). Carbonate rocks that separate the Vinodol Valley from the Adriatic coast are in the form of a brachianticline with a more steeply inclined north-eastern flank, whereas carbonates in the north-eastern valley flank exhibit a more complex tectonic structure. In the NW part of the Vinodol Valley, north-eastern carbonate rock slopes represent the steeply inclined south-western limb of the Cretaceous-Palaeogene anticline, while in the central and SE parts of the valley, they have a form of almost vertical cliffs formed by destruction of the top of the Cretaceous-Palaeogene anticline, overturned in a south-western direction (Blašković, 1999).

Flysch bedrock is mostly covered by different types of Quaternary deposits, among which the deposits originating from carbonate rock slopes are abundant (Đomlija, 2018). During the previous geological investigations, which are described in more detail in the following section, several types of the Quaternary deposits originating from carbonate rock slopes have been identified in the Vinodol Valley, based on the conventional field geological mapping. Šušnjar et al. (1970) first distinguished the talus, and the deluvial sediments (see Figure 1c). Blašković (1983) later conducted the most ex- tensive research of the Quaternary deposits in the Vinodol Valley, primarily focusing on deposits located between the Križišće and Grižane settlements. Knowledge of the types, hypsometrical positions, thicknesses and structural characteristics of the Quaternary carbonate breccias (Blašković, 1983) played an important role for the future reconstruction of tectonic evolution of the Vinodol Valley (Blašković, 1999). Within the framework of the recent geological and structural investigations, Palenik et al. (2019) produced a new geological map of the Vinodol Valley at a scale of 1:25.000 for the area between the Križišće and Kričina settlements (i.e., the Dubračina River Basin). A total of four informal lithostratigraphic units have been determined, belonging to the Quaternary sediments: $(i)$ rockfall breccias; (ii) deluvial-proluvial deposits; (iii) alluvial deposits; and (iv) rockfall deposits. According to their stratigraphic position, these informal lithostratigraphic units correspond to the Ivana Formation, belonging to the Pliocene and Holocene megasequence in the Croatian part of the Adriatic and the Dinaric areas (Velić et al., 2015; Šapina \& Vekić, 2015).

Tectonic activity during the Quaternary has been addressed as the main triggering factor for the gravitational 
movements of carbonate detritus to the hypsometrically lower portions of the Vinodol Valley (Blašković, 1999). Considering falls to be the only type or predominant type of movement, different types of superficial deposits consisting of carbonate rock fragments have been commonly designated by the term rockfall, added to the name of the identified material: for example, Quaternary rockfall breccia (Blašković, 1999), or Quaternary rockfall deposits (Palenik et al., 2019). Although gravitational mass movements were probably initiated predominantly by rockfalls triggered by strong earthquakes, the shapes, sizes and hypsometric positions of certain sedimentary bodies suggest that some other types of mass movements were also involved in their accumulation (Đomlija et al., 2019b).

So far, investigations of lithological materials in the Vinodol Valley have never been performed by applying remote sensing in a high resolution (e.g., Tarolli, 2014), which could allow the determination of types, boundaries and spatial distribution of the Quaternary deposits with high accuracy. In 2012, a Digital Terrain Model (DTM) at $1 \times 1 \mathrm{~m}$ spatial resolution was created for the whole area of the Vinodol Valley, from altitude data collected by airborne laser scanning (ALS) using the multireturn LiDAR (Light Detection and Ranging) system (Wehr and Lohr, 1999). The visual interpretation of high resolution (HR) LiDAR topographic derivatives enabled a much more detailed investigation of Quaternary deposits in the Vinodol Valley (Đomlija, 2018), which is otherwise significantly limited due to the dense vegetation and complex morphological conditions. This method is based on visual recognition and manual delineation of topographic features by an expert, using different types of visualizations in the form of LiDAR imagery derived from a DTM (e.g., Scaioni et al., 2014; Petschko et al., 2016), and has been broadly used in various lithological (e.g., Webster et al., 2006; Cavalli and Marchi, 2008; Notebaert et al., 2009; Sarala et al., 2015), geomorphological (e.g., Van Den Eeckhaut et al., 2007; Bell et al., 2012; Bernat Gazibara et al., 2019; Görüm, 2019; Đomlija et al., 2019a) and structural studies (e.g. Haugerud et al., 2003; Chen et al., 2015).

This paper presents the types and spatial distribution of the Quaternary deposits originating from carbonate rock slopes in the Vinodol Valley, which are identified and mapped based on the visual interpretation of four types of 1-m resolution LiDAR topographic derivatives, according the engineering geological principles. A total of six types of Quaternary deposits, referred to as engineering formations (Dearman, 1991), are identified and delineated in all three parts of the study area, with a high geographical accuracy of engineering formation boundaries and thematic accuracy, i.e., correctness of the lithological information. This study also presents the potential of the applied research method for identification and mapping of different types of superficial deposits in a study area characterized by complex geological and morphological conditions. The origin of the engineering materials identified in the Vinodol Valley is discussed in the context of different types of mass movements active during the Quaternary that could have led to their formation, and which topographical signatures are clearly observable on interpreted LiDAR derivatives.

\section{Previous investigations}

In the framework of the most detailed geological investigations of the Vinodol Valley conducted for the production of Basic Geological Map (BGM) at a scale of $1: 100.000$, Šušnjar et al. (1970) distinguished two types of the Quaternary chronostratigraphic units composed of sediments originated from carbonate rock slopes: (i) talus sediments, and (ii) deluvial sediments (see Figure 1c). The talus sediments are composed of unlithified angular carbonate cobbles and boulders, and are sporadically accumulated at the base of Palaeogene foraminiferal limestone in the NW part, and at the base of Cretaceous limestone in the SE part of the Vinodol Valley. The deluvial sediments are composed of heterogeneous soils originating from both the carbonate and flysch rocks, and cover the foot slopes of carbonate cliffs in the central part of the Vinodol Valley and hypsometrically, the lower parts of the flysch bedrock. Certain portions of both the talus sediments and deluvial sediments also encompass sedimentary bodies of Quaternary carbonate breccias (Grimani et al., 1973).

The first detailed description of the types and spatial distribution of Quaternary carbonate breccias was published by Blašković (1983). Based on the structural characteristics, the degree of lithification and the hypsometrical position, Blašković (1983) distinguished two types of the Quaternary carbonate breccias: (i) the older carbonate breccias; and (ii) the younger carbonate breccias (see Figure 2). Both types of these deposits were later determined as the Quaternary rockfall breccias, given that their origin has been ascribed to historical rockfalls triggered by seismic events during the tectonic evolution of the Vinodol area (Blašković, 1999).

Relatively large areas of the Quaternary carbonate breccias have been identified along the north-eastern flysch bedrock slopes, whereas smaller outcrops are sporadically located at the base of the south-western carbonate rock slopes (see Figure 2). The older carbonate breccias are strongly lithified, unsorted to poorly sorted clast-supported sedimentary rocks, composed of angular Upper Cretaceous and Palaeogene carbonate rock fragments with proximal average size of $20 \mathrm{~cm}$ (Blašković, 1983). These deposits have been identified in great thicknesses between the Dolinci and Barci settlements, where they form the solid bedrock for several small settlements (see Figure 2). Deposits are thickly bedded in places, with beds dipping toward the south-west at angles in a range between $15^{\circ}$ and $20^{\circ}$. Smaller breccia 


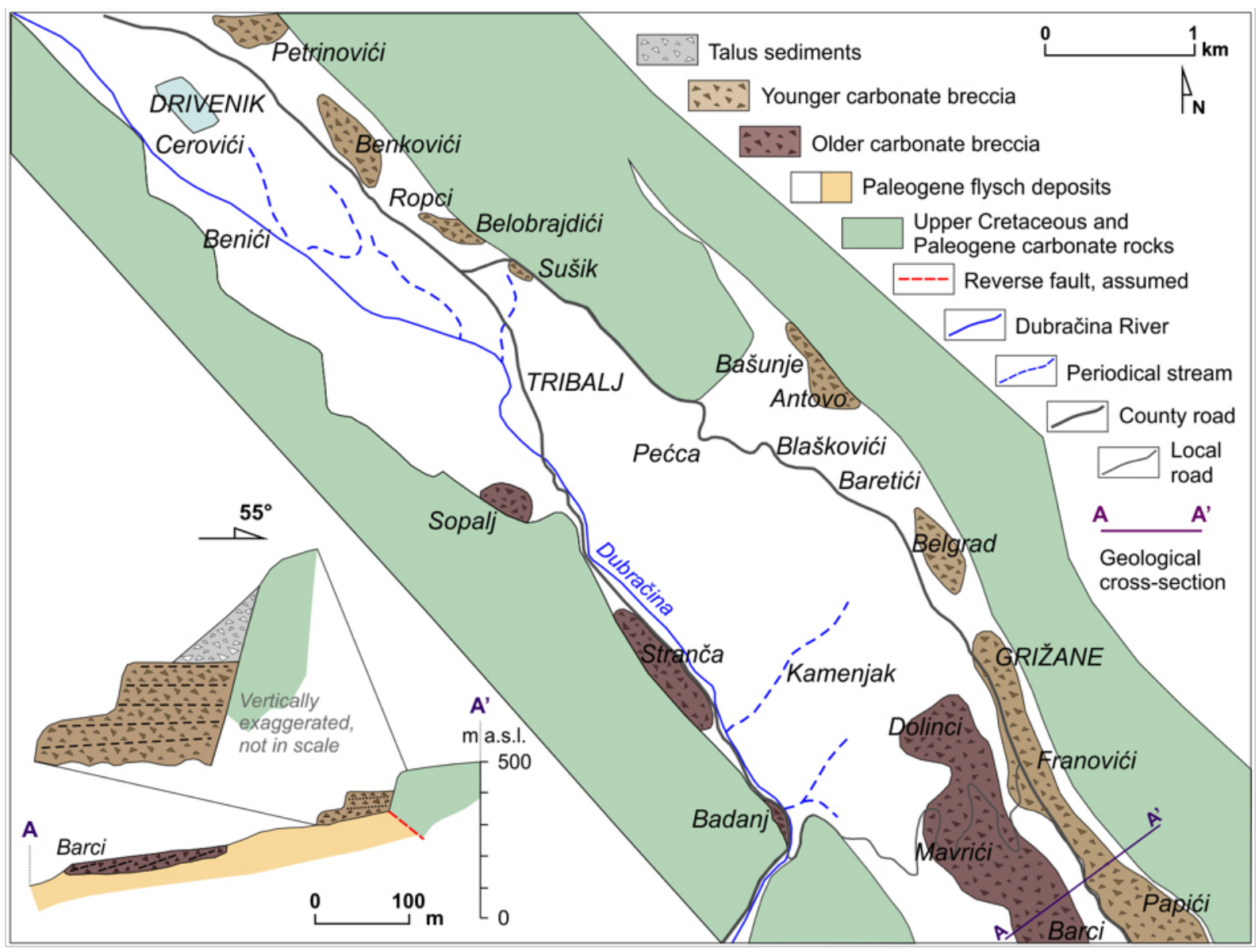

Figure 2: Types and distribution of the Quaternary carbonate breccias in the north-western and central parts of the Vinodol Valley, between the Petrinovići and Barci settlements (after Blašković, 1983)

outcrops at Stranča and Badanj localities (see Figure 2) are characterized by a much steeper bedding inclination, with beds dipping toward the north-eastern direction at angles in a range between $38^{\circ}$ and $44^{\circ}$ (Blašković, 1999).

The younger carbonate breccias are semi-lithified, poorly sorted clast-supported talus sedimentary successions, composed of angular to sub-rounded fragments of the Upper Cretaceous and Palaeogene carbonate rocks (Blašković, 1983). They are distributed along the northeastern flysch slopes in both the NW and central parts of the Vinodol Valley (see Figure 2). Sedimentary bodies are prominently stratified, with average thicknesses of bedding intervals in a range between 30 and $60 \mathrm{~cm}$. The bedding is distinctively coloured in places, due to the presence of varying amounts of fine-grained soils. The basal portions of sedimentary sequences are predominantly of a reddish grey colour, and the upper portions are predominantly yellow with sporadically grey intercalations. The younger carbonate breccias located at the hypsometrically highest positions are characterized by the lack of bedding and sorting, and often contain individual carbonate boulders.

The smallest approximated thicknesses of the Quaternary carbonate breccias are in the area of the Sušik $(\sim 10$ m), Bašunje ( $12 \mathrm{~m})$, Belobrajdići ( $18 \mathrm{~m})$, Ropci, Benkovići and Antovo $(\sim 25 \mathrm{~m})$ settlements, while the largest thicknesses are in the area of the Petrinovići, Franovići $(\sim 50 \mathrm{~m})$, Grižane $(\sim 70 \mathrm{~m})$ and Papići $(\sim 70$ $\mathrm{m})$ settlements (Blašković, 1983). The largest thicknesses of breccia deposits in the central part of the Vinodol Valley indicate the most intensive structural deformation of carbonate rocks along the north-eastern margin, whereas the gently inclined bedding of certain sedimentary bodies suggest the post-depositional tectonic activity that caused the uplift of the flysch bedrock and consequently changed the initially steeper orientation of the carbonate breccia deposits (Blašković, 1999).

The geological map of the Vinodol Valley at a scale 1:25.000 published by Palenik et al. (2019) shows that the informal lithostratigraphic unit of the Quaternary rockfall breccias is distributed only in a small area along the north-eastern part of the flysch slopes in the central part of the Vinodol Valley, i.e., in the wider area of the Blaškovići settlement located at the foot slope of the carbonate cliffs. Flysch bedrock is mostly covered by the Quaternary deluvial-proluvial deposits, composed of unsorted angular to sub-rounded carbonate rock fragments ranging in size from gravel to boulder mixed with fine-grained reddish soil. The Quaternary rockfall de- 

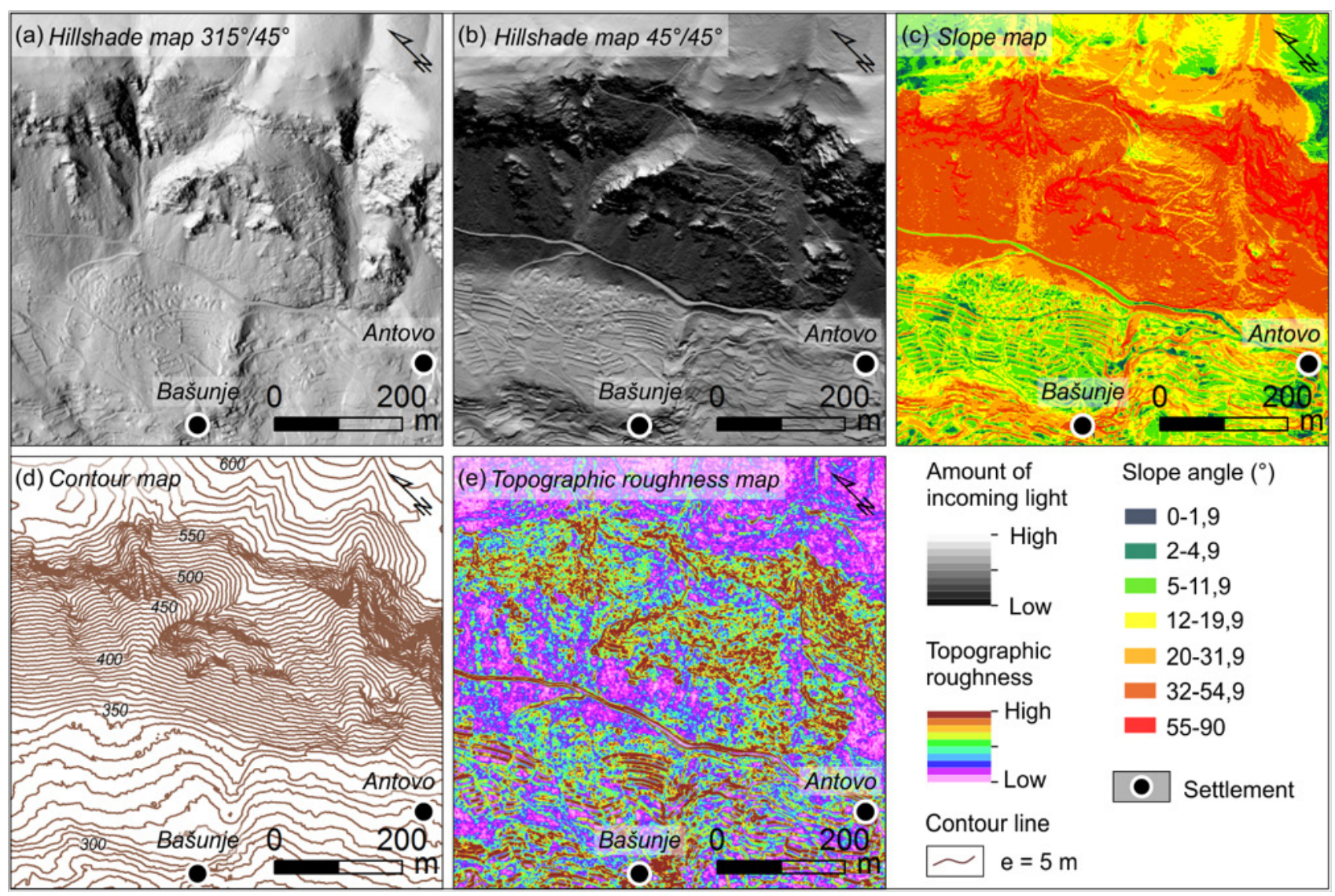

Figure 3: LiDAR topographic datasets derived from the 1 x $1 \mathrm{~m}$ DTM and visually interpreted in the study:

(a) the hillshade map with sun illumination parameters of $315^{\circ} / 45^{\circ}$; (b) the hillshade map with sun illumination parameters of $45^{\circ} / 45^{\circ}$; (c) the slope map; (d) the contour map with 5-m contour line intervals; (e) the topographic roughness map.

posits, representing the unlithified angular carbonate rock fragments of various sizes, are distributed along both margins of the Vinodol Valley, being more frequent and of larger areas at the base of the carbonate rock cliffs.

\section{Materials and methods}

\subsection{Airborne LiDAR data and high resolution topographic derivatives}

The LiDAR data used in this study were acquired in March 2012 by airborne laser scanning using the multireturn laser scanning system (Wehr \& Lohr, 1999). Point measurements were post-processed and filtered into returns from all objects and vegetation, and returns from the bare ground. The bare ground returns were acquired at the point density of 4 points $/ \mathrm{m}^{2}$, with an average point distance of $0.5 \mathrm{~m}$, and were used for the creation of the DTM at $1 \times 1 \mathrm{~m}$ spatial resolution. The average accuracy of the elevation data is $30 \mathrm{~cm}$.

Four types of high resolution (HR) LiDAR topographic datasets (i.e., LiDAR maps, LiDAR derivatives) were used for identification and mapping of the Quaternary deposits originated from carbonate rock slopes in the Vinodol Valley, and were derived from the DTM us- ing standard tools in ArcGIS 10.0 software (see Figure 3): (i) the hillshade maps; (ii) the slope map; (iii) the contour maps; and (iv) the topographic roughness (i.e., terrain ruggedness) map. Three hillshade maps were derived from the DTM using the sun azimuth angles of $315^{\circ}$ and $45^{\circ}$, and the sun elevation angles of $45^{\circ}$ and $30^{\circ}$. No vertical exaggeration was used. Although the hillshade map with sun illumination parameters of $315^{\circ} / 45^{\circ}$ was the one mostly used during the visual analysis, hillshade maps were additionally overlapped in two combinations, in order to obtain the optimal shaded relief for each part of the study area: (i) the semi-transparent (50\%) hillshade map $45^{\circ} / 45^{\circ}$ over the hillshade map $315^{\circ} / 45^{\circ}$, and (ii) the semi-transparent (50\%) hillshade map $45^{\circ} / 30^{\circ}$ over the hillshade map $315^{\circ} / 45^{\circ}$. The contour maps were derived with $1-\mathrm{m}$ and $5-\mathrm{m}$ contour line intervals. The topographic roughness map was calculated according to the Slope Variability Method (e.g., Ruszkiczay-Rüdiger et al., 2009; Popit \& Verbovšek, 2013), using the slope map as the input parameter.

\subsection{Visual interpretation of HR LiDAR topographic derivatives}

The visual interpretation of HR LiDAR topographic derivatives was performed in two steps: (i) preliminary; 

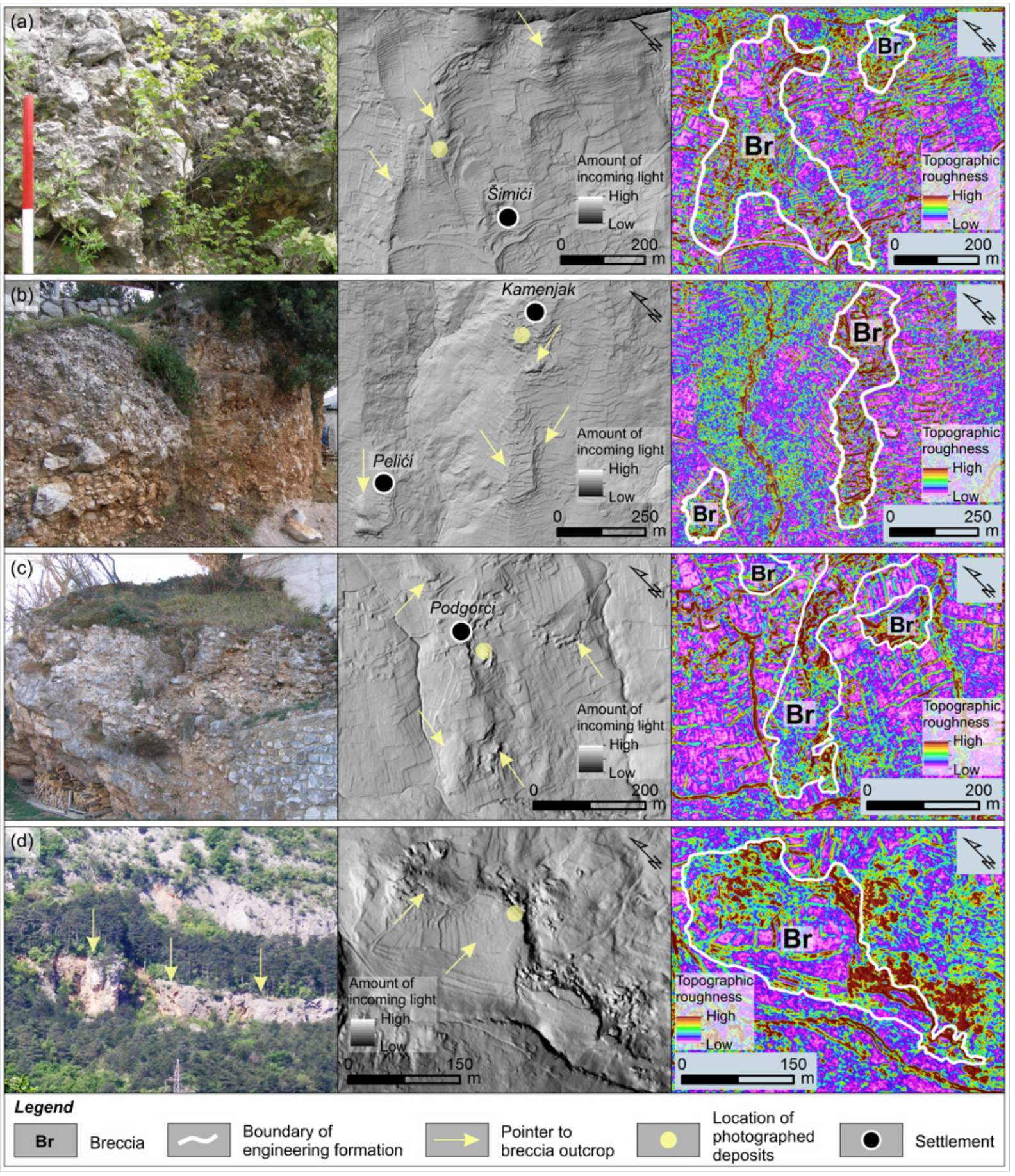

Figure 4: Photographs and examples of topography of breccia outcrops on (from left to right) the hillshade map and the topographic roughness map, identified in: (a) the north-western part; (b) and (c) the central part, and

(d) the south-eastern part of the Vinodol Valley.

and (ii) detailed. The main objective of the preliminary visual interpretation was to determine the possibilities for unambiguous identification and mapping of different types of Quaternary sediments originated from carbonate rock slopes directly from LiDAR derivatives, and to establish the criteria for their identification and precise mapping, respectively. It was carried out for smaller portions in all three parts of the Vinodol Valley, which were evaluated as representative for the diversity of engineer- ing materials, based on the visual analysis of the hillshade map and the contour maps, accompanied by field reconnaissance mapping. The LiDAR maps were visually analysed individually and in different combinations (e.g., contour maps over the slope map, semi-transparent slope map over the hillshade map), through repeated interpretation phases, to determine which LiDAR map or their combination best reflect a particular material. This analysis was performed simultaneously with field recon- 
Types and distribution of Quaternary deposits originating from carbonate rock slopes in the Vinodol Valley...

Table 1: Descriptive statistics for the area of sedimentary bodies of the engineering formation of breccia $(\mathrm{Br})$

\begin{tabular}{|l|c|c|c|c|c|c|c|}
\hline \multirow{2}{*}{$\begin{array}{l}\text { No. of polygons } \\
\text { of breccia (Br) }\end{array}$} & \multicolumn{7}{|c|}{ Area, $\boldsymbol{A}\left(\mathbf{m}^{\mathbf{2}}\right)$} \\
\cline { 2 - 9 } & Tot & Avg & Min & $\begin{array}{c}\mathbf{2 5}^{\text {th }} \\
\text { percentile }\left(\mathbf{Q}_{\mathbf{1}}\right)\end{array}$ & $\begin{array}{c}\mathbf{5 0}^{\text {th }} \\
\text { percentile }\left(\mathbf{Q}_{\mathbf{2}}\right)\end{array}$ & $\begin{array}{c}\mathbf{7 5}^{\text {th }} \\
\text { percentile }\left(\mathbf{Q}_{\mathbf{3}}\right)\end{array}$ & Max \\
\hline 63 & $1.848,232$ & 29,337 & 322 & 3,474 & 7,971 & 18,013 & 466,760 \\
\hline
\end{tabular}

naissance mapping, in order to verify the remote sensing results already in the earliest phase of investigation.

The detailed visual interpretation of LiDAR derivatives involved the identification and precise manual delineation of different types of Quaternary deposits originated from carbonate rock slopes in the entire study area according to the established criteria. They represented the characteristic sets of recognition features indicative for particular engineering material coupled with the LiDAR maps that are considered to be the most effective for their identification and precise delineation of boundaries. The main recognition features that have enabled identification of particular materials on LiDAR derivatives are shape, appearance, morphometric characteristics and geomorphological setting of sedimentary bodies, as well as certain anthropogenic features. The identification of individual sedimentary bodies was performed by screening the LiDAR derivatives relative to their sizes, at scales mostly in a range between 1:1,000 and 1:5,000. The manual delineation of polygons was carried out on considerably larger scales, ranging between 1:500 and 1:1,000.

\subsection{Field verification, soil sampling and laboratory tests}

The verification of the remote sensing results was performed by field checks during the winter and early spring months in 2015 and 2016, due to the spars and leaf-off periods. It was conducted at more than 230 reconnaissance mapping sites in all three parts of the Vinodol Valley. Field checks were partially limited, due to the difficult access to morphologically complex terrain parts, as well as terrain parts covered by dense shrubs and forest.

A total of six soil samples were taken from the superficial deposits only in the NW part of the Vinodol Valley, by using a shovel. The particle-size analysis was performed according to the British Standards (BS 13377-2, 2010), including the sieve analysis for the coarsegrained, and the hydrometer analysis for the fine-grained soil samples components. All soils were sieved by applying the wet sieving method.

\section{Results}

\subsection{Types of the Quaternary deposits originating from carbonate rock slopes}

There are six types of the Quaternary deposits originating from carbonate rock slopes identified in the Vinodol Valley, based on the visual interpretation of HR
LiDAR topographic derivatives. These are: $(i)$ breccia $(\mathrm{Br})$; $(i i)$ older talus $\left(\mathrm{B}_{\mathrm{s} 1}\right) ;(i i i)$ recent talus $\left(\mathrm{B}_{\mathrm{s} 2}\right) ;(i v)$ boulders and olistoliths (B,Ol); (v) proximal proluvium $\left(\mathrm{GS}_{\mathrm{pr}}\right)$; and ( $\left.v i\right)$ distal proluvium (GS-SG $\mathrm{Gr}_{\mathrm{pr}}$. They are referred to as engineering geological units of a rank of engineering formations (Dearman, 1991), given the type, physical state and attribute of homogeneity of identified engineering material. Engineering descriptions and symbols of engineering formations are defined according to the general principles of engineering geological mapping given in Dearman (1991).

\subsubsection{Breccia $(\mathrm{Br})$}

The engineering formation of breccia $(\mathrm{Br})$ includes engineering material of soft to moderately soft rudaceous sedimentary rock, composed of angular carbonate rock fragments strongly cemented by carbonate cement (see photographs in Figure 4). The rock fragments predominantly have sizes of gravel and cobbles. Certain breccia outcrops, such as the one presented in Figure 4c, are characterized by horizontal to gently inclined bedding, with a bedding thickness ranging between a few decimetres and $>1$ meter.

Individual breccia outcrops are clearly visible and thus relatively easily recognizable on the hillshade map (marked with yellow arrows in Figure 4). They are characterized by elongated (see Figure 4a-c) or irregular shapes (see Figure 4d), a rough appearance along the outcrop edges (e.g., Figure 4d), and abrupt changes in slope angles between the outcrop edges and the surrounding slopes, clearly marked on the slope map (Đomlija, 2018). In most cases, there is a higher topographic roughness of breccia outcrops in relation to the surrounding flysch bedrock slopes, clearly expressed on the topographic roughness map (see Figure 4).

The engineering formation of breccia $(\mathrm{Br})$ includes a total of 63 delineated polygons (see Table 1). Its total area is $1.85 \mathrm{~km}^{2}$. The smallest breccia outcrop has an area of $322 \mathrm{~m}^{2}$, whereas the largest outcrop has an area of 0.47 $\mathrm{km}^{2}$. However, $75 \%$ of the identified breccia outcrops have an area that is less than approximately $18,000 \mathrm{~m}^{2}$.

\subsubsection{Older talus $\left(B_{s 1}\right)$}

The engineering formation of older talus $\left(\mathrm{B}_{\mathrm{s} 1}\right)$ includes engineering material in scree cones and scree aprons, composed of very coarse composite soil represented by angular to sub-rounded carbonate rock fragments, whose sizes range from gravel to massive boulders (see photographs in Figure 5). They are sporadi- 

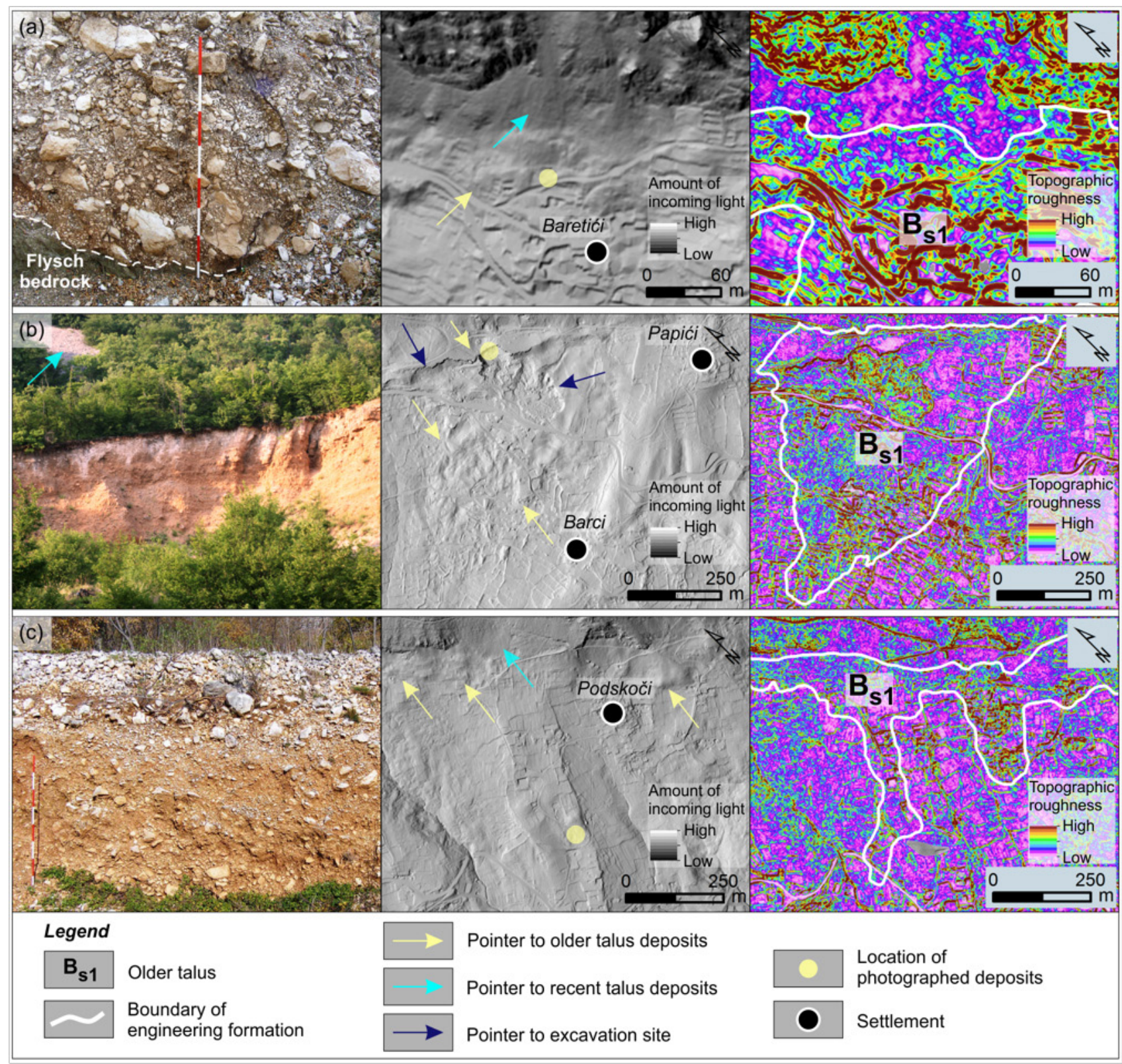

Figure 5: Photographs and examples of topography of older talus deposits on (from left to right) the hillshade map and the topographic roughness map, identified in: (a) and (b) the central part; (c) the south-eastern part of the Vinodol Valley.

cally mixed with a lot of fine-grained soils of reddish and yellowish colour. Portions of the older talus $\left(\mathrm{B}_{\mathrm{s} 1}\right)$ are sporadically weakly cemented, but the engineering material can still be excavated by a shovel or an excavator (Đomlija, 2018), and therefore represents engineering soil (Dearman, 1991). The boundary between the older talus $\left(\mathrm{B}_{\mathrm{s} 1}\right)$ and flysch bedrock is determined in the field only in the Baretići settlement, in the central part of the Vinodol Valley (see Figure 5a). The total area of older talus $\left(\mathrm{B}_{\mathrm{ss}}\right)$ in the Vinodol Valley is $3.07 \mathrm{~km}^{2}$.

Sedimentary bodies of older talus deposits can be easily identified on the hillshade map in uninhabited areas and areas without marked traces of agricultural activities. The main recognition features are fan-like and tongue-like shapes, and hummocky topography (marked with yellow arrows in Figures 5a, c). The shapes of older talus deposits are also clearly visible on the contour map with 5-m contour line intervals (Đomlija, 2018). Geomorphological setting is another important recognition feature of older talus deposits, given that their proximal segments are located at the base of the carbonate rock slopes and cliffs and are partially covered by the recent talus (marked with cyan arrows in Figures 5a, c). The boundary between the older talus $\left(\mathrm{B}_{\mathrm{s} 1}\right)$ and recent talus $\left(\mathrm{B}_{\mathrm{s}}\right)$ is marked by distinctive changes in slopes angles easily recognizable on the slope map (Đomlija, 2018). However, the topographic roughness map (see Figure 5) clearly reflects the strong textural differences 


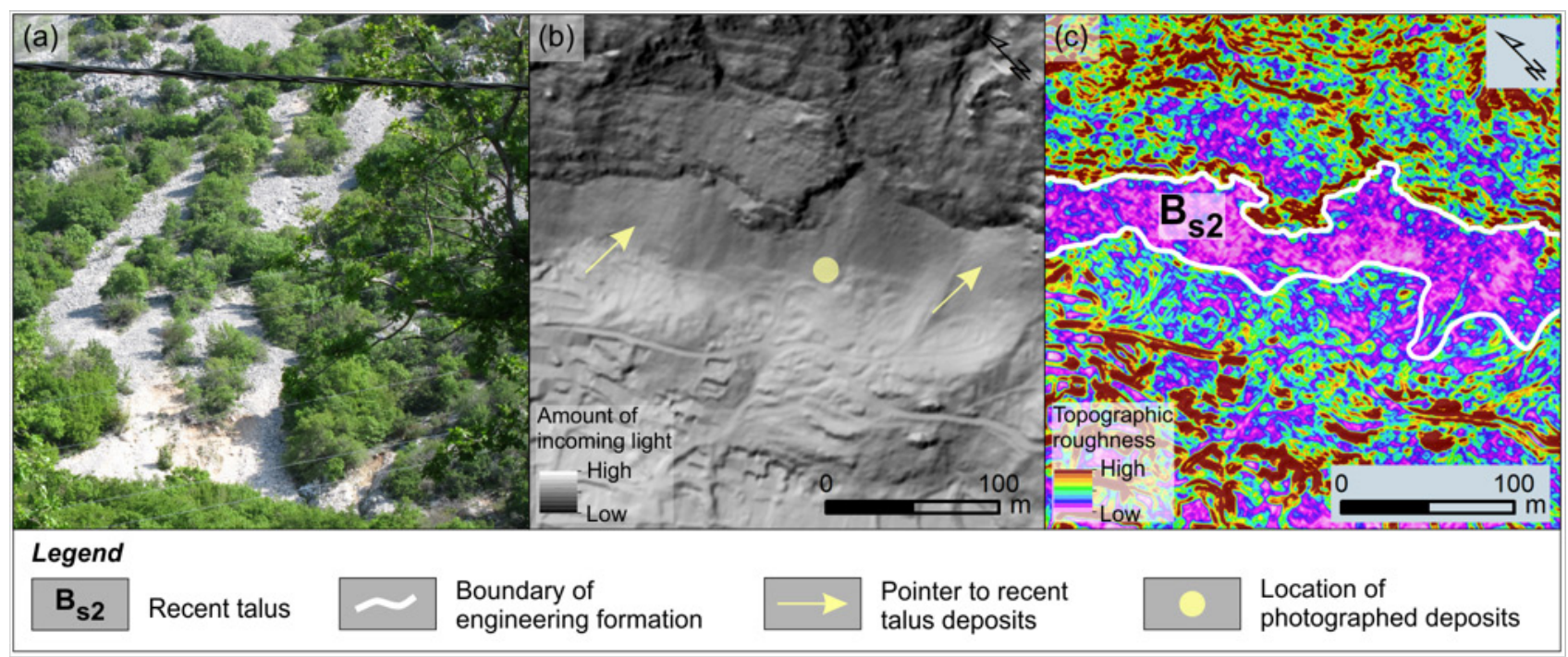

Figure 6: (a) Photograph; and an example of topography of recent talus deposits on (b) the hillshade map; and (c) the topographic roughness map, identified in the central part of the Vinodol Valley.

between the rougher older talus $\left(\mathrm{B}_{\mathrm{s1}}\right)$ and the relatively smooth recent talus $\left(\mathrm{B}_{\mathrm{s}}\right)$, and therefore is considered as the most effective LiDAR map for precise delineation of their boundary.

On the other hand, in populated and agricultural areas, older talus deposits are difficult, if not impossible to recognize directly on LiDAR derivatives, due to their modified topography (Đomlija, 2018). However, certain anthropogenic features, such as the material excavation sites (marked by blue arrows in Figure 5b), partially aimed at the identification of older talus deposits on LiDAR maps. In order to identify the lower boundary of the older talus $\left(\mathrm{B}_{\mathrm{s} 1}\right)$ within the populated areas, field reconnaissance mapping was carried out at numerous mapping sites. The boundary was subsequently delineated based on the interpretation of field mapping data coupled with the visual interpretation of the contour map with 5-m contour line intervals (Đomlija, 2018).

\subsubsection{Recent talus $\left(B_{s 2}\right)$}

The engineering formation of a recent talus $\left(\mathrm{B}_{\mathrm{s} 2}\right)$ includes engineering material in scree cones and scree aprons, composed of very coarse composite soil represented by angular, small to massive carbonate rock boulders mixed with some fine-grained soil (see Figure 6a). The total area of the recent talus $\left(\mathrm{B}_{\mathrm{s} 2}\right)$ in the Vinodol Valley is $1.54 \mathrm{~km}^{2}$.

Recent talus deposits can be unambiguously identified directly on LiDAR derivatives, primarily based on their geomorphological setting at the base of the carbonate rock slopes and cliffs (marked by yellow arrows in Figure 6b). Their cone-like shaped sedimentary bodies are mostly located at the endings of chutes formed along the cliffs (Đomlija et al., 2019b), and are clearly observable on the contour map with 1-m contour line inter- val (Đomlija, 2018). They are also specific for a smooth topography expressed on the topographic roughness map (see Figure 6c), which served as the most effective map for delineation of the recent talus $\left(\mathrm{B}_{\mathrm{s} 2}\right)$.

\subsubsection{Boulders and olistoliths $(B, O l)$}

The engineering formation of boulders and olistoliths $(\mathrm{B}, \mathrm{Ol})$ includes engineering material in individual sedimentary bodies composed of very coarse composite soil represented by carbonate rock massive boulders and olistoliths (see photograph in Figure 7a), which are irregularly distributed along the flysch bedrock slopes. In most cases, elongated or irregularly shaped individual sedimentary bodies can be easily identified on the hillshade map (marked by yellow arrows in Figure 7), as well as the topographic roughness map, due to their rougher texture in relation to the texture of the surrounding flysch slopes. In hypsometrically lower parts of the slopes in the central and SE parts of the Vinodol Valley, sedimentary bodies of boulders and olistoliths are particularly easily distinguished from their surroundings in cases when they are located in areas marked by remnants of agricultural terraces (e.g., Figure 7b).

The total area of the engineering formation of boulders and olistoliths (B,Ol) in the Vinodol Valley is $0.41 \mathrm{~km}^{2}$. It includes a total of 20 delineated polygons (see Table 2). The smallest sedimentary body has an area of $1,884 \mathrm{~m}^{2}$, and the largest has an area of $79,557 \mathrm{~m}^{2}$. However, $75 \%$ of sedimentary bodies have an area $<32,299 \mathrm{~m}^{2}$.

\subsubsection{Proximal proluvium $\left(G S_{p r}\right)$}

The engineering formation of proximal proluvium $\left(\mathrm{GS}_{\mathrm{pr}}\right)$ includes engineering material in proximal segments of proluvial fans accumulated at the base of the carbonate rock slopes, composed of stratified coarse 


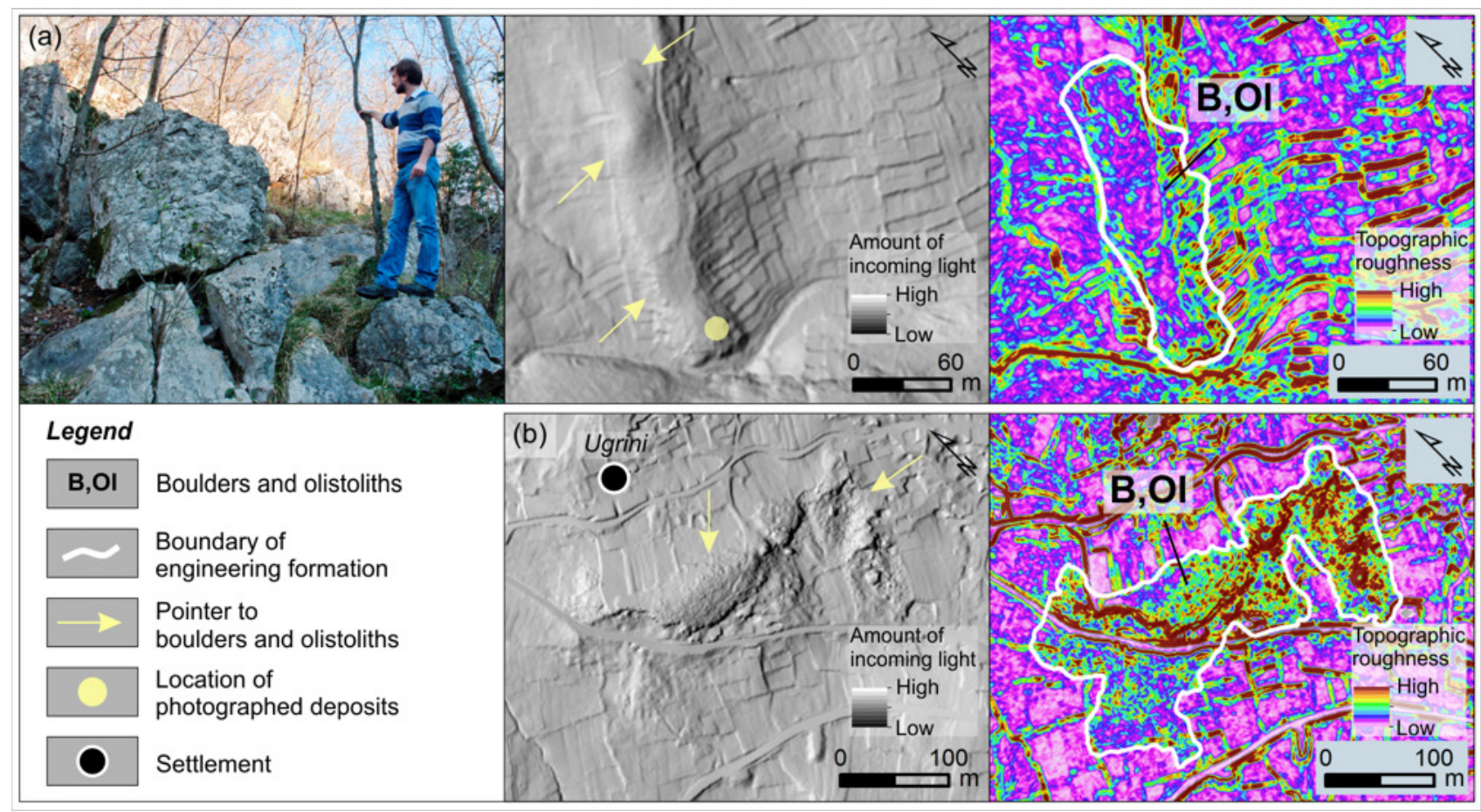

Figure 7: A photograph and examples of topography of boulders and olistoliths sedimentary bodies on (from left to right) the hillshade map and the topographic roughness map, identified in: (a) the north-western part;

(b) the south-eastern part of the Vinodol Valley.

Table 2: Descriptive statistics for the area of sedimentary bodies of the engineering formation of boulders and olistoliths $(\mathrm{B}, \mathrm{Ol})$

\begin{tabular}{|l|c|c|c|c|c|c|c|}
\hline \multirow{2}{*}{$\begin{array}{l}\text { No. of polygons } \\
\text { of boulders and } \\
\text { olistoliths (B,OI) }\end{array}$} & \multicolumn{7}{|c|}{ Area, $\left.\boldsymbol{A} \mathbf{( m}^{\mathbf{2}}\right)$} \\
\cline { 2 - 9 } & Tot & Avg & Min & $\begin{array}{c}\mathbf{2 5}^{\text {th }} \\
\text { percentile }\left(\mathbf{Q}_{\mathbf{1}}\right)\end{array}$ & $\begin{array}{c}\mathbf{5 0}^{\text {th }} \\
\text { percentile }\left(\mathbf{Q}_{\mathbf{2}}\right)\end{array}$ & $\begin{array}{c}\mathbf{7 5}^{\text {th }} \\
\text { percentile }\left(\mathbf{Q}_{3}\right)\end{array}$ & $\mathbf{M a x}$ \\
\hline 20 & 405,012 & 20,251 & 1,884 & 3,972 & 11,006 & 32,299 & 79,557 \\
\hline
\end{tabular}

composite soils predominantly consisting of carbonate gravel and blocks (see Figures 8a, b). According to the particle-size analysis (BS 13377-2, 2010), four soil samples are well graded gravel (GW), while one soil sample is poorly graded gravel with sand (GP). Gravel particles are angular to sub-rounded. In some portions of sedimentary bodies, gravels are coated by a fine-grained reddish soil, whose amounts may vary considerably along the engineering formation, and may be abundant in places. Proximal proluvial deposits sporadically also include various amounts of angular to sub-rounded carbonate cobbles and boulders. Certain portions are weakly cemented (see Figure 8c). The total area of the proximal proluvium $\left(\mathrm{GS}_{\mathrm{pr}}\right)$ in the Vinodol Valley is $1.04 \mathrm{~km}^{2}$.

The hillshade map reveals the hummocky topography of proximal proluvial fans, particularly in places without visible traces of construction or agricultural activities (see Figure 8d). The fan-like shaped sedimentary bodies can be easily recognized on the contour map, while the slope map clearly reflects distinctive changes in slope angles between the carbonate rock slopes and proximal proluvium (see Figure 8e). The relatively smooth topography is, in most cases, clearly observable on the topo- graphic roughness map (Đomlija, 2018). Excavation sites of the engineering material (marked with a blue arrow in Figure 8d), which has been exploited mainly for reconstruction of the roads in the Vinodol Valley, also aided in the identification of proximal proluvial deposits.

\subsubsection{Distal proluvium $\left(G S-S G_{p r}\right)$}

The engineering formation of distal proluvium (GSSGpr) includes engineering material in distal segments of proluvial fans accumulated at the base of the carbonate rock slopes, composed of partially stratified coarse composite soils consisted of vertically and laterally various amounts gravel and sand, mixed with much reddish fine-grained soil (see Figures 9a, b). The particle-size analysis (BS 13377-2, 2010) was performed for only one soil sample, which represents well graded gravel with sand $(\mathrm{GW})$. Gravel particles are angular to sub-rounded, and coated by a fine-grained soil. Deposits may sporadically include carbonate rock boulders (Đomlija, 2018). The total area of the distal proluvium $\left(\mathrm{GS}_{-} \mathrm{SG}_{\mathrm{pr}}\right)$ in the Vinodol Valley is $2.05 \mathrm{~km}^{2}$.

Distal proluvium deposits could not be unambiguously identified directly on LiDAR derivatives. No char- 


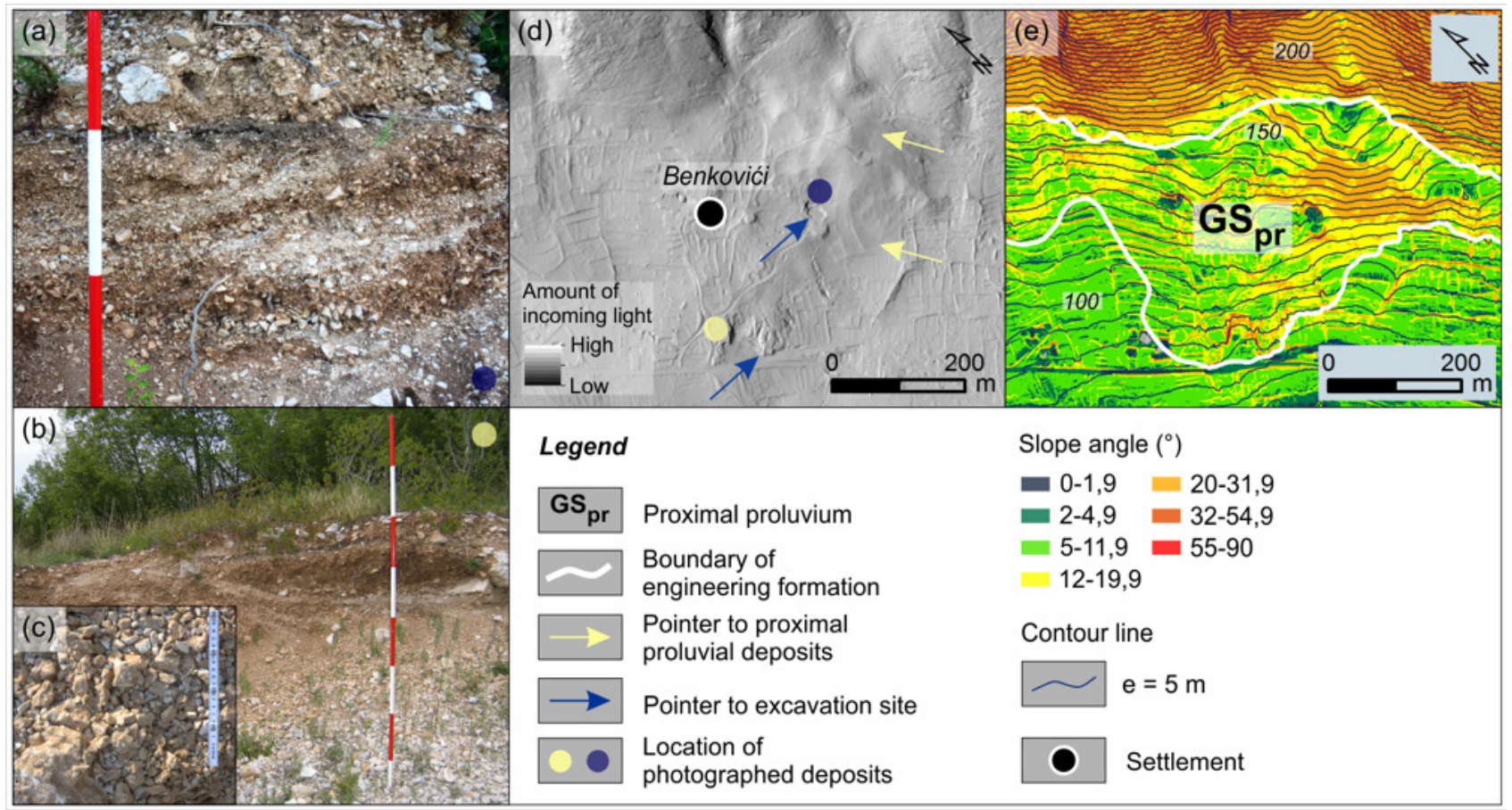

Figure 8: (a) - (c) Photographs; and examples of topography of proximal proluvial deposits on (d) the hillshade map; and (e) the contour map with 5-m contour line interval over the slope map, identified in the north-western part of the Vinodol Valley.

acteristic features of distal proluvial fans are clearly expressed on the hillshade map (see Figure 9c), whereas their fan-like shapes are only sporadically and partially expressed on the contour map (see Figure 9d). Changes in slope angles are marked only along the knick lines between the proximal proluvial and distal proluvial deposits, whereas they are much less clearly expressed along the boundary between the distal proluvial deposits and the hypsometrically lower slopes (see Figure 9d). This is partially because these areas are mostly inhabited, so their topography has been modified by construction works and agricultural terracing. Therefore, extensive field reconnaissance mapping was carried out in order to identify the lower boundary of the distal proluvium $\left(\mathrm{GS}-\mathrm{SG}_{\mathrm{pr}}\right)$. The delineation was subsequently performed based on interpretation of field mapping data coupled with a visual interpretation of the contour maps.

\subsection{Spatial distribution of the Quaternary deposits originated from carbonate rock slopes}

The spatial distribution of the Quaternary deposits originated from carbonate rock slopes in the Vinodol Valley is presented in Figure 10. Seven cross-sections are also constructed for characteristic slope portions in different parts of the Vinodol Valley (see Figure 11). The thicknesses of the engineering formations presented in the cross-sections are approximated based on the interpretation of data published by Blašković (1983), and field reconnaissance mapping. The areas of engineering formations in different parts of the Vinodol Valley are presented in Figure 12.
The breccia $(\mathrm{Br})$ formation has the largest total area in the central part of the Vinodol Valley (see Figure 12). The largest breccia outcrops, characterized by pronounced elongated shapes, were identified in the areas of the Franovići and Mavrići $\left(A=0.47 \mathrm{~km}^{2}\right)$, Barci $(A=$ $\left.0.25 \mathrm{~km}^{2}\right)$, and Kamenjak $\left(A=0.08 \mathrm{~km}^{2}\right)$ settlements (see Figure 10b; cross-section D-D' in Figure 11). The maximum lengths of two largest sedimentary bodies are similar and both greater than $1 \mathrm{~km}$, i.e., the sedimentary body in the area of the Franovići and Mavrići settlements has a length $L=1,080 \mathrm{~m}$, whereas the sedimentary body in the area of the Barci settlement has a length $L=1,054 \mathrm{~m}$. Smaller and irregularly shaped breccia outcrops were identified in the area of the Belgrad, Grižane, Pelići, Miroši and Kričina settlements, with areas in a range between $A=7,775 \mathrm{~m}^{2}$ and $A=32,818 \mathrm{~m}^{2}$, and near the Badanj locality $\left(A=7,731 \mathrm{~m}^{2}\right)$ at the base of the south-western carbonate rock slopes (see Figure 10). In the SE part of the Vinodol Valley, relatively large and elongated outcrops were identified near the Kosavin $(A$ $\left.=0.16 \mathrm{~km}^{2} ; L=748 \mathrm{~m}\right)$ and Podgorci $\left(A=46,451 \mathrm{~m}^{2} ; L\right.$ $=545 \mathrm{~m})$ settlements, where their toes almost reached the riverbed of the Suha Ričina River (see Figure 10c; cross-section E-E' in Figure 11). Another relatively large breccia outcrop $\left(A=0.12 \mathrm{~km}^{2}\right)$, surrounded by several smaller irregularly shaped outcrops, was identified near the Kičeri settlement (see Figure 10c; cross-section G-G' in Figure 11). In the NW part of the Vinodol Valley, only one large and elongated breccia sedimentary body $\left(A=0.12 \mathrm{~km}^{2}, L=713 \mathrm{~m}\right)$ was identified near the Šimići settlement (see Figure 10a; cross-section A-A' in Figure 11). Several smaller breccia outcrops are located 


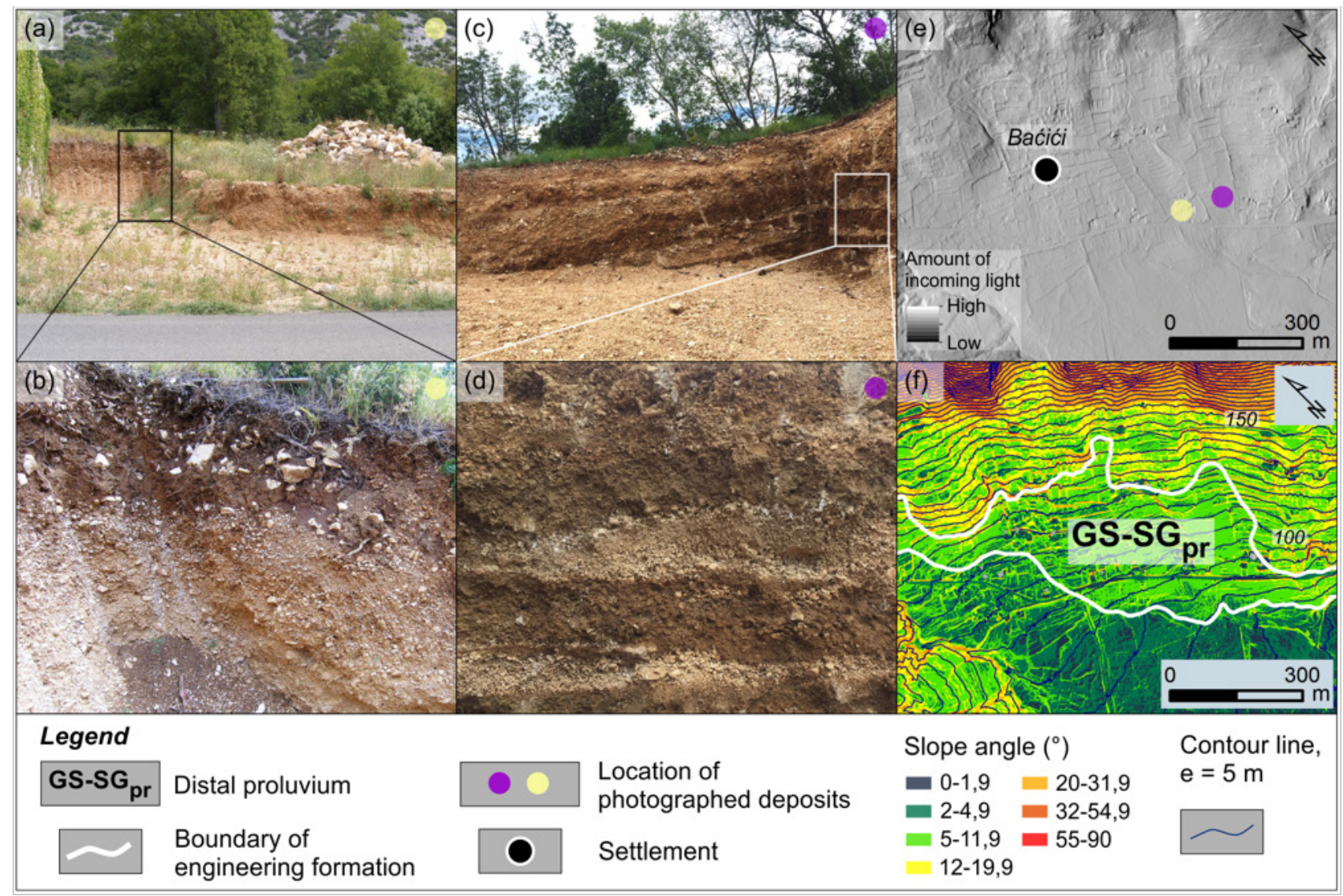

Figure 9: (a) - (d) Photographs; and examples of topography of distal proluvial deposits on (e) the hillshade map; and (f) the contour map with 5-m contour line interval over the slope map, identified in the north-western part of the Vinodol Valley.

near the Ropci $\left(A=18,000 \mathrm{~m}^{2}\right)$ and Križišće $(A=3,875$ $\left.\mathrm{m}^{2}\right)$ settlements.

The older talus $\left(\mathrm{B}_{\mathrm{s} 1}\right)$ has the form of an almost continuous sheet at the base of the carbonate rock slopes in both valley margins, in all three parts of the Vinodol Valley (see Figure 10). The largest total area of the older talus $\left(\mathrm{B}_{\mathrm{s} 1}\right)$ is in the SE part of the Vinodol Valley (see Figure 12), where the prominently elongated deposits are continuously distributed between the Kričina settlement and the hinterland of the town of Novi Vinodolski (see Figure 10c). Distal parts of older talus deposits reach the hypsometrically lowest positions near the Stale (see cross-section F-F' in Figure 11) and Ugrini settlements, and then further in the south-eastern direction. The approximate maximum lengths of older talus deposits range between $L=499 \mathrm{~m}$ (near the Ugrini settlement) and $L=724 \mathrm{~m}$ (near the Štale settlement).

In the central part of the Vinodol Valley, the largest and prominently elongated sedimentary body of older talus deposits was identified between the breccia outcrops located in the area of the Franovići and Barci settlements (see Figure 10b). Its length is $L=807 \mathrm{~m}$. Similar elongated shapes of older talus deposits, but characterized by smaller areas, were identified near the Baretići and Kričina settlements, and near the Semičevići settlement at the base of the south-western carbonate rock slopes. The older talus $\left(\mathrm{B}_{\mathrm{s} 1}\right)$ has the smallest total area in the NW part of the Vinodol Valley (see Figure 12), where it was identified only at the base of the carbonate rock slopes along the south-western margin (see Figure 10a).

The recent talus $\left(\mathrm{B}_{\mathrm{s} 2}\right)$ forms a more-or-less continuous sheet at the base of the carbonate rock slopes and cliffs along the north-eastern valley margin (see Figure 10). The largest total area of the recent talus $(B)$ is in the central part of the Vinodol Valley (see Figure 12), where recent talus cones are the most abundantly distributed between the Baretići and Marušići settlements, and near the Miroši settlement (see Figure 10b). In the NW part of the Vinodol Valley, recent talus deposits mostly cover the apexes of proximal proluvial fans (see Figure 11, cross-section B-B'), whereas in the SE part of the Vinodol Valley, a recent talus predominantly covers proximal parts of older talus deposits between the Podskoči and Kičeri settlements (see Figure 10c).

The boulders and olistoliths $(\mathrm{B}, \mathrm{Ol})$ has the largest total area in the central part of the Vinodol Valley (see Figure 12). Two relatively large sedimentary bodies, characterized by similar elongated shapes, were identified between the Antovo and Blaškovići settlements $(A=$ $\left.0.08 \mathrm{~km}^{2} ; L=332 \mathrm{~m}\right)$, and near the Miroši settlement ( $A$ 


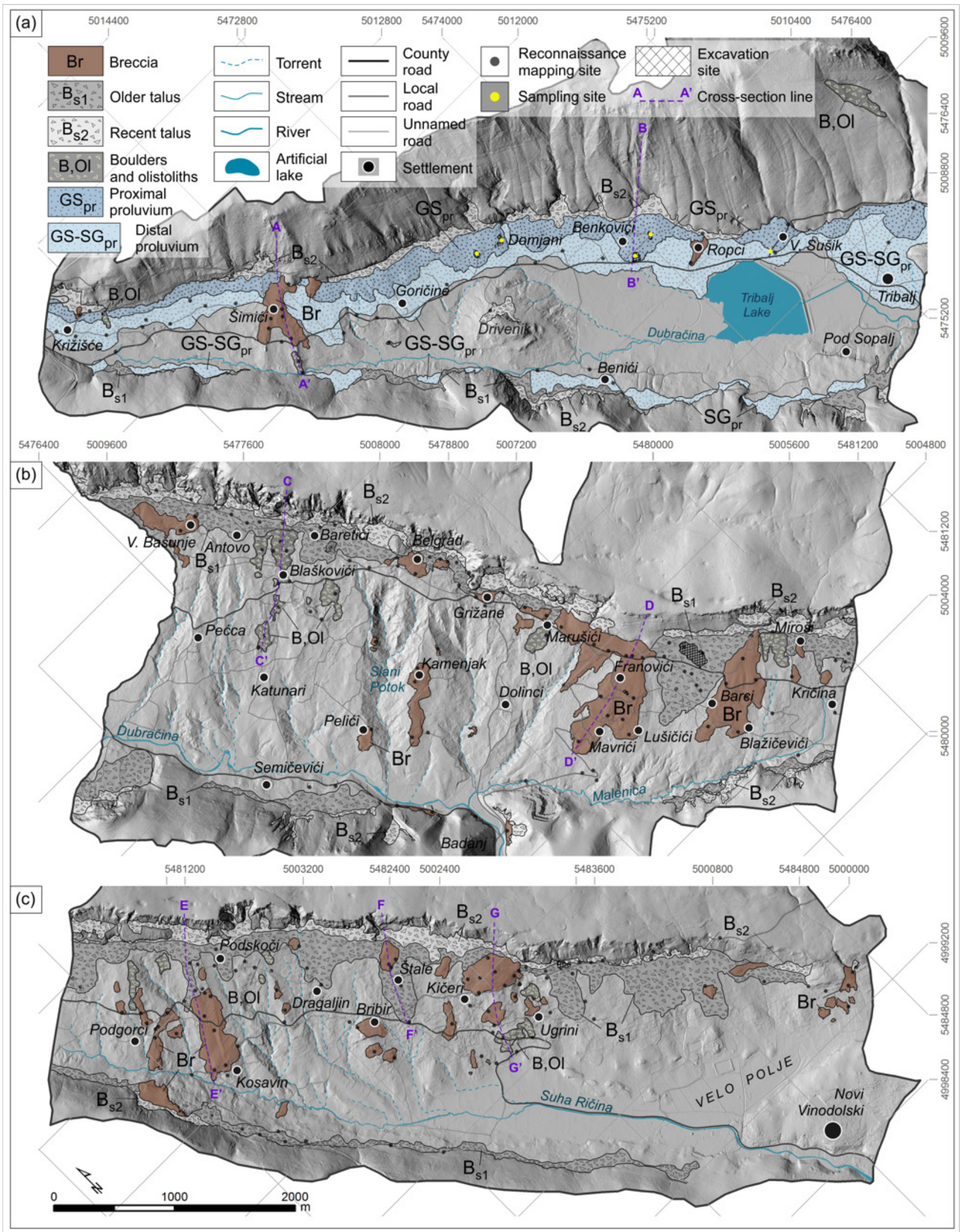

Figure 10: Spatial distribution of the Quaternary deposits originated from carbonate rock slopes in: (a) the north-western part; (b) the central part; and (c) the south-eastern part of the Vinodol Valley 


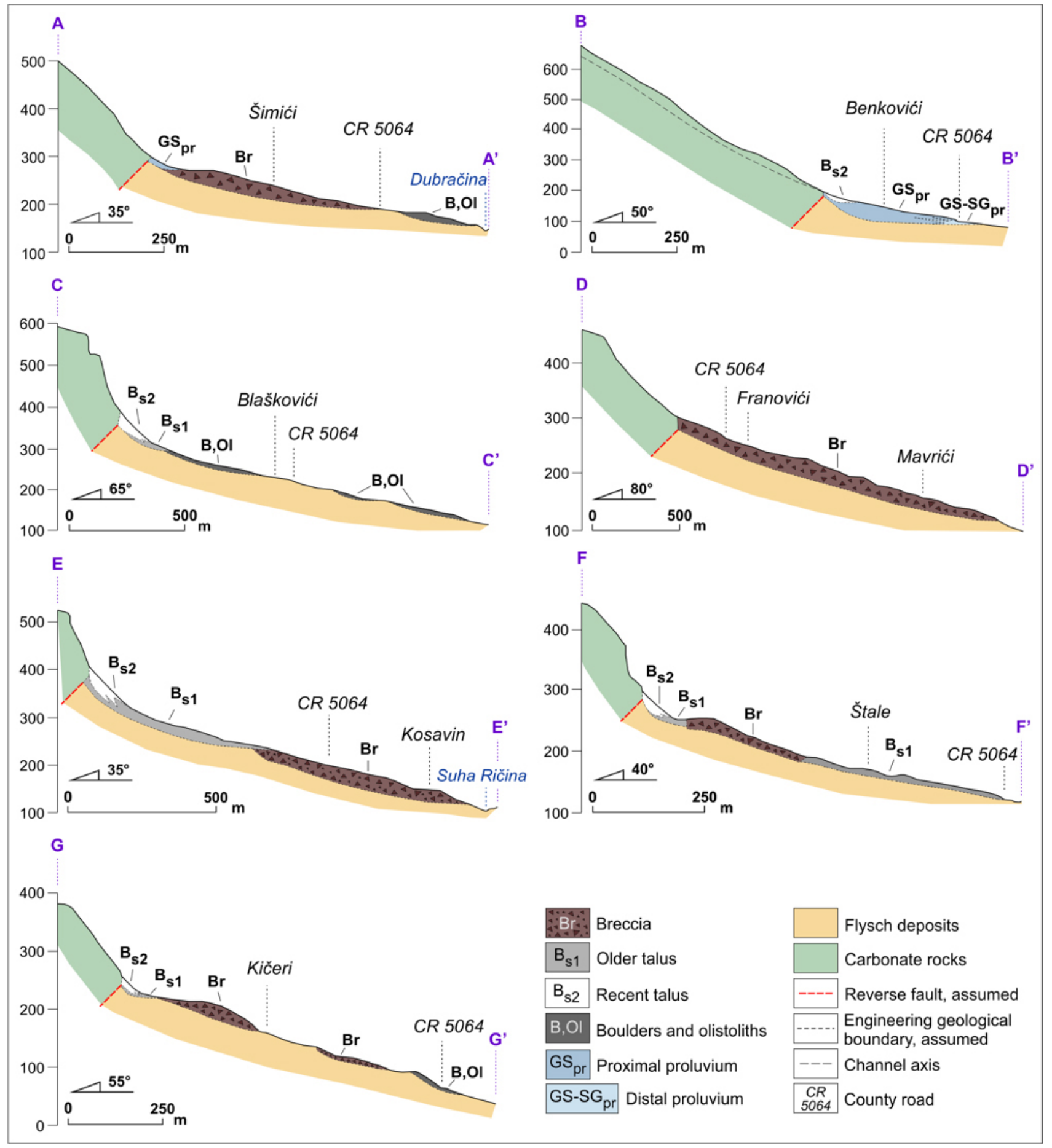

Figure 11: Characteristic cross-sections of the Vinodol Valley, with respect to the spatial distribution of the Quaternary deposits originated from carbonate rock slopes. The positions of the cross-sections are presented in Figure 10.

$=0.05 \mathrm{~km} ; L=289 \mathrm{~m})$. Sedimentary bodies located between the Blaškovići, Pećca and Katunari, and between the Grižane and Dolinci settlements (see Figure 10b), have a patchy occurrence and are irregularly shaped, similar to the occurrences and shapes of sedimentary bodies located near the Ugrini settlement in the SE part of the Vinodol Valley (see Figure 10c). The smallest total area of the boulders and olistoliths $(\mathrm{B}, \mathrm{Ol})$ is in the NW part of the Vinodol Valley (see Figure 12), where the largest accumulation was identified at the carbonate rock slope above the Tribalj settlement (see Figure 10c).

The proximal proluvium $\left(\mathrm{GS}_{\mathrm{pr}}\right.$ ) and distal proluvium $\left(\mathrm{GS}_{\mathrm{SG}} \mathrm{SG}_{\mathrm{pr}}\right.$ ) were identified only in the NW part of the Vinodol Valley, at the base of the carbonate rock slopes dissected by numerous channels incised by surface water flow (see Figure 10c). The largest proluvial fans, and thus the largest estimated thicknesses of proluvial deposits, are in the wider area between the Domjani, 


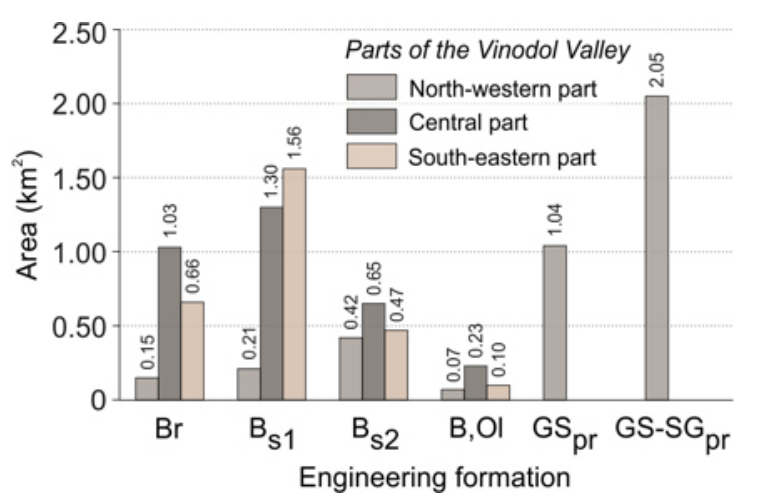

Figure 12: Total areas of engineering formations in different parts of the Vinodol Valley. For engineering formations legends see Figure 10.

Benkovići, Veli Sušik and Tribalj settlements (see Figure 11, cross-section B-B').

\section{Discussion}

In this study, the visual interpretation of HR LiDAR topographic derivatives was proven as an appropriate method for the identification and mapping of engineering materials over a relatively large study area, given that six different types of engineering formations (Dearman, 1991) were identified and precisely delineated, and their spatial distribution was determined in detail. Most of the engineering materials were easily recognizable directly on the hillshade map, already during the preliminary visual interpretation. The clear expression of individual sedimentary bodies on the LiDAR DTM strongly directed and aimed the field reconnaissance mapping necessary for accurate identification of engineering materials, and also enabled the establishment of criteria for their identification and mapping, once their specific topographic pattern was determined. It is the establishment of criteria combined with iterative field checks that significantly contributed to the quality and accuracy of the obtained remote sensing results and reduced subjectivity in the research, which is by a certain degree commonly involved within studies based on the visual interpretation of HR LiDAR topographic derivatives (e.g., Guzzetti et al., 2012; Petschko et al., 2016).

The highest degree of geographic accuracy is considered to characterize the boundaries of the breccia $(\mathrm{Br})$, recent talus $\left(\mathrm{B}_{\mathrm{s2}}\right)$ and boulders and olistoliths $(\mathrm{B}, \mathrm{Ol})$, due to the characteristic shapes of individual sedimentary bodies that are, in most cases, clearly visible on LiDAR derivatives (see Figures 4, 6, 7). Thereby, it was the easiest to identify and map the largest breccia outcrops characterized by distinctively marked edges, located in the area of the Franovići, Mavrići and Barci settlements in the central part, and in the area of the Podgorci, Kosavin and Kičeri settlements in the SE part of the Vinodol Valley (see Figure 10). On the other hand, there is the potentially reduced geographical accuracy of lower boundary of the older talus $\left(\mathrm{B}_{\mathrm{s} 1}\right)$ in populated areas and terrains with agricultural terraces, due to the lack of recognition of the characteristic shapes of sedimentary bodies on LiDAR maps. Characteristic fan-like shapes of proluvial deposits could also not be clearly identified on LiDAR maps within populated areas; therefore the geographical accuracy of certain portions of the proximal proluvium $\left(\mathrm{GS}_{\mathrm{pr}}\right)$ and distal proluvium $\left(\mathrm{GS}-\mathrm{SG}_{\mathrm{pr}}\right)$ is also potentially reduced.

However, both the proximal proluvium $\left(\mathrm{GS}_{\mathrm{pr}}\right)$ and distal proluvium ( $\mathrm{GS}_{-} \mathrm{SG}_{\mathrm{pr}}$ ) are characterized by a high degree of thematic accuracy, given their geomorphological settings at the base of the carbonate rock slopes dissected by numerous channels formed by the surface water flow (see Figure 10). A high degree of thematic ac-

Table 3: Types of landslides (Hungr et al., 2014) that formed sedimentary bodies of engineering formations identified in the Vinodol Valley. See Figure 10 for examples of sedimentary body locations.

\begin{tabular}{|l|l|l|}
\hline $\begin{array}{l}\text { Landslide type (Hungr et al., 2014) that formed } \\
\text { sedimentary bodies of an engineering formation }\end{array}$ & Engineering formation & $\begin{array}{l}\text { Examples of locations of sedimentary } \\
\text { bodies of an engineering formation }\end{array}$ \\
\hline \multirow{2}{*}{ Rockfall } & Recent talus $\left(\mathrm{Bs}_{2}\right)$ & Antovo, Belgrad, Grižane \\
\cline { 2 - 3 } & Older talus $\left(\mathrm{Bs}_{1}\right)$ & \\
\cline { 2 - 3 } & Breccia $(\mathrm{Br})$ & Belgrad, Grižane \\
\hline \multirow{2}{*}{ Rock irregular slide } & Recent talus $\left(\mathrm{Bs}_{2}\right)$ & Grižane \\
\cline { 2 - 3 } & Older talus $\left(\mathrm{Bs}_{1}\right)$ & Grižane, Podskoči \\
\hline Rock rotational slide & Breccia $(\mathrm{Br})$ & Kičeri \\
\hline \multirow{2}{*}{ Rock avalanche } & Breccia $(\mathrm{Br})$ & Kamenjak, Mavrići, Barci, Kosavin \\
\cline { 2 - 3 } & Older talus $\left(\mathrm{Bs}_{1}\right)$ & Lušičići, Podskoči, Štale, Ugrini \\
\hline & Boulders and olistoliths $(\mathrm{B}, \mathrm{Ol})$ & Šimići, Blaškovići, Katunari, Miroši \\
\hline \multirow{2}{*}{ Debris flow } & Recent talus $\left(\mathrm{Bs}_{2}\right)$ & Domjani, Benkovići \\
\hline & Older talus $\left(\mathrm{Bs}_{1}\right)$ & Kričina, Dragaljin \\
\hline & Breccia $(\mathrm{Br})$ & Ropci, Velo Polje \\
\cline { 2 - 3 } & Proximal proluvium $\left(\mathrm{GS}_{\mathrm{pr}}\right)$ & Domjani, Benković, Tribalj \\
\cline { 2 - 3 } & Distal proluvium $\left(\mathrm{GS}-\mathrm{SG}_{\mathrm{pr}}\right)$ & \\
\hline
\end{tabular}



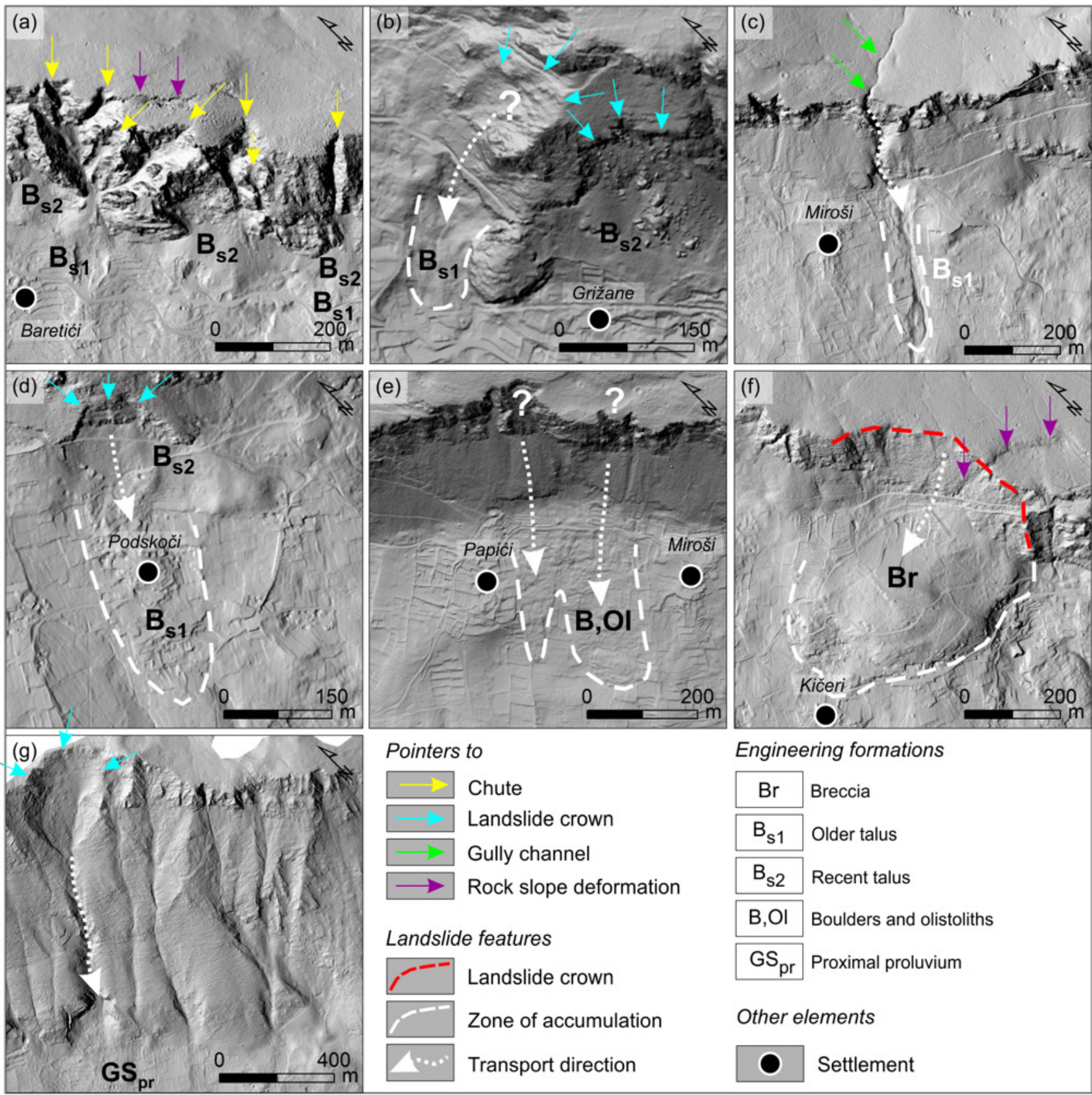

Pointers to

Engineering formations

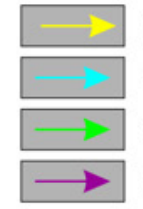

Chute

Landslide crown

Gully channel

Rock slope deformation

\section{Landslide features}

\begin{tabular}{l} 
Zone of accumulation \\
\hline$\ldots$ Transport direction
\end{tabular}

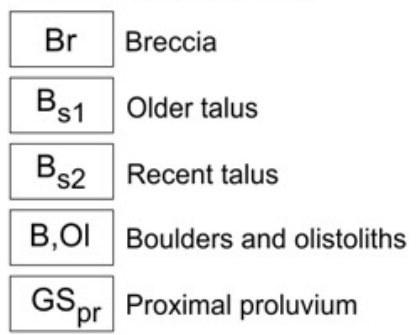

\section{Other elements}

Settlement

Figure 13: Types of landslides (Hungr et al., 2014) that formed sedimentary bodies of engineering formations identified in the Vinodol Valley: (a) rockfalls, indicated by chutes formed along the carbonate cliffs marked by yellow arrows; (b) rock irregular slides, indicated by landslide crowns marked by cyan arrows; (c) debris flow, formed along the gully channel marked by green arrow; (d) rock avalanche, initiated by rock irregular slide; (e) zones of accumulation of probably two rock avalanche events;

(f) rock rotational slide, indicated by landslide scarp marked by red arrows; (g) debris flow, probably initiated by rock collapse marked by cyan arrows. Purple arrows in (a) and (f) point to rock slope deformations.

curacy due to the geomorphological setting is also considered for the recent talus $\left(\mathrm{B}_{\mathrm{s} 2}\right)$ and older talus $\left(\mathrm{B}_{\mathrm{s} 1}\right)$, although it can potentially be reduced for certain portions of the older talus deposits $\left(\mathrm{B}_{\mathrm{s} 1}\right)$ in parts of the study area where field reconnaissance mapping was limited (for example, in the area near the Velo Polje in the SE part of the Vinodol Valley; see Figure 10). The breccia $(\mathrm{Br})$ and boulders and olistoliths $(\mathrm{B}, \mathrm{Ol})$ are characterized by the greatest similarity of shapes and morphometric characteristics of individual sedimentary bodies on
LiDAR derivatives, which becomes more pronounced with a decrease in the size of breccia outcrops (see Figures 4,7 ). This is particularly specific for breccia outcrops and boulders and olistoliths identified in the SE part of the Vinodol Valley, in the area near the Podgorci, Dragaljin and Ugrini settlements (see Figure 10c). Therefore, in order to obtain the highest possible degree of thematic accuracy in the identification and mapping of these deposits, it was necessary to conduct multiple field checks of the remote sensing results. 
Although the origin of the Quaternary deposits from carbonate rock slopes, in particular the origin of carbonate breccias, has so far been generally assigned to rockfalls (e.g., Blašković, 1999), new insight into the shapes, geometric characteristics and hypsometrical positions of identified sedimentary bodies support the speculations that some other types of gravitational mass movements, and not just rockfalls, played an important role in the formation of individual sedimentary bodies of different types of engineering materials in the Vinodol Valley (see Table 3). Presumptions about the different types of landslides (Hungr et al., 2014) that led to the formation of different types of engineering materials are also strongly indicated based on certain topographic features of carbonate rock slopes and cliffs identified on LiDAR derivatives (see Figure 13).

Rockfalls are considered to be the predominant landslide type for the formation of the sedimentary bodies of the recent talus $\left(\mathrm{B}_{\mathrm{s} 2}\right)$ and older talus $\left(\mathrm{B}_{\mathrm{s} 1}\right)$ in the Vinodol Valley, primarily based on the identification of numerous chutes (marked by yellow arrows in Figure 13a) formed at specific places along carbonate cliffs where falling processes occur more frequently (Selby, 1993). A total of 118 chutes were identified in the Vinodol Valley, with a total area of $0.36 \mathrm{~km}^{2}$ (Đomlija et al., 2019b). Individual breccia outcrops located in the hypsometrically higher portions of flysch bedrock slopes and at the base of carbonate cliffs (see Table 3 for examples of locations) probably also represent the zones of accumulation of relatively large rockfall events. Certain portions of sediments that are delineated within the engineering formations of the older talus $\left(\mathrm{B}_{\mathrm{s} 1}\right)$ and recent talus $\left(\mathrm{B}_{\mathrm{s} 2}\right)$ have been formed by rock irregular slides (landslide crowns marked by cyan arrows in Figure 13b), as well as by ephemeral debris flows (see Figure 13c). Rockfalls are still active on the carbonate rock slopes and cliffs in all three parts of the Vinodol Valley, as numerous scars of recent landslide phenomena and overhanging blocks were identified in the field (Đomlija et al., 2019b). The last recorded debris flow event was in August 2016 (Đomlija, 2018), whose zone of accumulation covered a section of the county road passing through the Marušići settlement in the central part of the Vinodol Valley (see Figure 10).

Given the predominantly elongated shapes of the sedimentary bodies identified in this study (see Figure 10), it is probable that rock avalanche events of different magnitudes occurred in the Vinodol Valley during the Quaternary. Those events could probably have led to the formation of the largest breccia sedimentary bodies identified in the Vinodol Valley, as well as to the formation of certain portions of the older talus $\left(\mathrm{B}_{\mathrm{s} 1}\right)$ (see Table 2). Certain topographic signatures indicative for the zones of depletion of landslides suggest that some rock avalanches were probably initiated by large rockfalls or rock irregular slides, i.e., rock collapses (marked by cyan arrows in Figure 13d), triggered by moderate or strong earthquakes. It is also presumed that the sedimentary bodies of the boulders and olistoliths $(\mathrm{B}, \mathrm{Ol})$ mainly represent the zones of accumulation of fossil rock avalanches, some of which are considered to have been formed by two separate flow events (e.g., example in Figure 13e; Đomlija et al., 2019b).

The morphological characteristics of individual breccia sedimentary bodies, as well as of their potential source areas, indicate that the rock rotational sliding (Hungr et al., 2014) also took place in the formation of the breccia (Br). Such an example is presented in Figure 13f, which reflects the semilunar shape of the carbonate cliff portion that probably represents the main scarp of the landslide, and elliptical-like shape of the breccia outcrop that is presumably the main body of the landslide. Given the similar morphological features of carbonate cliffs recognizable on the hillshade map in the area between the Belgrad and Grižane settlements (see Figure 10), it is possible that breccia outcrops located beneath the carbonate cliffs in this area also originate from a rock rotational slide, despite their smaller area and slightly different geometry from the geometry of the breccia outcrop presented in Figure 13f.

The aforementioned presumptions are as well supported by the presence of different types of Quaternary sediments originated from carbonate rock slopes identified in the Vipava Valley, SW Slovenia (Jež, 2007; Popit \& Košir, 2010; Popit et al., 2014), which is characterized by similar geological and geomorphological conditions as those in the Vinodol Valley, i.e., Mesozoic carbonates overthrust on Palaeogene flysch, resulting in steep carbonate rock slopes and cliffs along the northeastern border (Placer, 2008). According to investigations conducted over the last 10 years, most of these Quaternary sediments in the Vipava Valley represent the zones of accumulation of fossil landslides that occurred during the near and distant geological past (Popit et al., 2017). For example, the largest fan-shaped sedimentary body identified in the Vipava Valley, known as the Selo landslide, represents the zone of accumulation of a highmagnitude rock avalanche probably initiated by a largescale rock collapse (Verbovšek et al., 2017). Radiocarbon dating of wood debris contained within the carbonate gravel sediments of the Selo landslide indicates that the landslide event occurred during the Late Pleistocene, with the presumed age of more than $42 \mathrm{ka}$ (Popit \& Košir, 2003). Another large fossil rock avalanche in the Vipava Valley is known as the Gradiška Gmajna landslide, which has deposited a large amount of Quaternary sediments together with the Selo landslide, in thicknesses reaching up to $50 \mathrm{~m}$ (Popit et al., 2017). Furthermore, several sedimentary bodies composed of carbonate rock fragments, and certain poorly stratified breccia outcrops identified in the Vipava Valley represent large-scale deep-seated rotational landslides (Popit et al., 2017). The most recent investigations conducted by Kocjančić et al. (2019) indicate that a total of 10 carbonate mega- 
blocks (e.g., Mala Gora, Križec, Visoko) represent both translational and rotational movements of carbonate material over the flysch bedrock initiated from the carbonate cliffs along the north-eastern valley margin, probably triggered by major earthquake events.

Differences between the results of previous investigations and the results obtained in this study refer to both the amount of types of identified lithological materials, and their significantly different spatial distribution along the study area (see Figures 2, 10). Quaternary sediments identified in the NW part of the Vinodol Valley mostly represent the engineering soils deposited by multiple debris flow events (e.g., Figure 13g), and not only the carbonate breccias formed by the intensive structural deformation of carbonate rocks along the north-eastern margin (Blašković, 1999). However, despite certain differences in the spatial distribution, the engineering formations identified in this study can be correlated with informal lithostratigraphic units determined by Palenik et al. (2019), where the older talus $\left(\mathrm{B}_{\mathrm{s} 1}\right)$, recent talus $\left(\mathrm{B}_{\mathrm{s} 2}\right)$ and boulders and olistoliths $(\mathrm{B}, \mathrm{Ol})$ correspond to the rockfall deposits, the proximal proluvium $\left(\mathrm{GS}_{\mathrm{pr}}\right)$ and distal proluvium (GS-SG $\mathrm{pr}_{\mathrm{pr}}$ ) correspond to the deluvialproluvial deposits, and the breccia $(\mathrm{Br})$ corresponds to the rockfall breccias. Taking into account the prominent historical and instrumentally recorded seismicity of the study area (Palenik et al., 2019), and the upcoming climate changes, the stratigraphy, sedimentology and origin of Quaternary deposits in the Vinodol Valley need to be further investigated in more detail, partly because of the question whether similar landslide events could occur in the present age, given that morphological features indicative of rock slope deformations (Hungr et al., 2014) are in places visible along the carbonate cliffs (marked with purple arrows in Figure 13a, f).

\section{Conclusions}

In this study, six different types of the Quaternary deposits originating from carbonate rock slopes in the Vinodol Valley were identified based on the visual interpretation of four types of $1 \times 1 \mathrm{~m}$ LiDAR topographic datasets. Sedimentary bodies of a total area of approximately $10 \mathrm{~km}^{2}$ are delineated with the highest geographic and thematic accuracy of boundaries, given the applied innovative technique and adopted methodology. Identified lithological materials were classified according to engineering geological principles, and they represent the engineering formations.

The results of this study indicate that the Quaternary deposits originating from carbonate slopes cover $15 \%$ of the Vinodol Valley $\left(64.57 \mathrm{~km}^{2}\right)$. Among the identified engineering formations, the older talus $\left(\mathrm{B}_{\mathrm{S} 1}\right)$ has the largest total area $\left(3.07 \mathrm{~km}^{2}\right)$, whereas the boulders and olistoliths (B,Ol) have the smallest total area $\left(0.41 \mathrm{~km}^{2}\right)$. Sedimentary bodies of both engineering formations are most abundant in the central part of the Vinodol Valley. The engineering formation of breccia $(\mathrm{Br})$ covers approx. 3\% of the Vinodol Valley, and breccia outcrops are predominantly present in its central and SE parts. Proximal proluvium $\left(\mathrm{GS}_{\mathrm{pr}}\right.$ ) and distal proluvium (GS-SG $\mathrm{prr}$ ) predominate in the NW part of the Vinodol Valley, with the cumulative total area of $3.09 \mathrm{~km}^{2}$.

The visual interpretation of HR LiDAR topographic derivatives was proven to be an effective method for the identification and mapping of superficial deposits, particularly for the identification and mapping of relatively large sedimentary bodies with distinctive shapes and morphometric characteristics. However, the experience gained in this research suggests that in study areas characterized by complex geological conditions and pronounced remnants of anthropogenic features, the preliminary visual interpretation of LiDAR derivatives accompanied by field investigations must not be neglected. This is particularly important if certain lithological materials are characterized by morphological similarity on LiDAR DTM, such as the breccia (Br) and boulders and olistoliths $(\mathrm{B}, \mathrm{Ol})$ in this study, because the lack of mapping criteria and extensive field checks may significantly reduce the thematic accuracy of the remote sensing results.

Unlike previous investigations of Quaternary sediments in the Vinodol Valley, which addressed their origin directly to the tectonic evolution of the study area and rockfalls, this research brings the origin of the identified engineering materials into relation with some other landslide types. The shapes and sizes of individual sedimentary bodies, as well as the topographic signatures of their potential source areas along the carbonate rock slopes and cliffs visible on LiDAR DTM, indicate that rock avalanche, rock irregular slide and debris flow events played an important role in the formation of different types of Quaternary deposits in this study area. Thereby, it is indicative that rock avalanches were the most active in the central and SE parts of the Vinodol Valley, where they probably have formed most of the sedimentary bodies of breccia $(\mathrm{Br})$, older talus $\left(\mathrm{B}_{\mathrm{s} 1}\right)$ and boulders and olistoliths (B,Ol). Similar Quaternary deposits in Vipava Valley (SW Slovenia) that have been found to represent fossil landslides serve as an important argument in the presumption that certain Quaternary deposits in the Vinodol Valley also represent the zones of accumulation of fossil landslide events, given the almost exactly same geological conditions in the two study areas. Finally, the identified types of Quaternary deposits originating from carbonate rock slopes and their spatial distribution along the entire Vinodol Valley represent a valuable basis for further detailed investigations, not only of fossil landslide phenomena, but also of their exact age, paleoclimate significance and general reconstruction of the Quaternary geodynamic processes in the Vinodol area. 


\section{Acknowledgment}

The presented results have been obtained in the framework of the Croatian-Japanese bilateral project Risk Identification and Land-Use Planning for Disaster Mitigation of Landslides and Floods in Croatia, funded by the Japan Science and Technology Agency (JST) and the Japan International Cooperation Agency (JICA) through the Science and Technology Research Partnership for Sustainable Development (SATREPS) Program. This work has also been supported in part by the Ministry of Science, Education and Sports of the Republic of Croatia under the project Research Infrastructure for Campus-based Laboratories at the University of Rijeka, number RC.2.2.06-0001. The project has been co-funded by the European Fund for Regional Development (ERDF). We thank three anonymous reviewers for their constructive comments.

\section{References}

Bell, R., Petschko, H., Röhrs, M. and Dix, A. (2012): Assessment of landslide age, landslide persistence and human impact using airborne laser scanning digital terrain models. Geografiska Annaler: Series A, Physical Geography, 94, 135-156. doi: 10.1111/j.1468-0459.2012.00454.x

Bernat Gazibara, S., Krkač, M. and Mihalić Arbanas, S. (2019): Landslide inventory mapping using LiDAR data in the City of Zagreb (Croatia). Journal of Maps, 15, 773779. doi: 10.1080/17445647.2019.1671906

Blašković, I. (1983): O rasprostranjenosti i položaju pliocenskih i kvartarnih taložina u Vinodolu (About Distribution and Position of Pliocene and Quaternary Sediments at Vinodol). Geološki vjesnik, 36, 27-35. (in Croatian - English abstract)

Blašković, I. (1999): Tectonics of Part of the Vinodol Valley within the Model of the Continental Crust Subduction. Geologia Croatica, 52/2, 153-189. doi: 10.4154/GC.1993.13

BS 1377-2 (2010). Methods of test for soils for civil engineering purposes. Classification tests.

Cavalli, M. and Marchi, L. (2008): Characterisation of the surface morphology of an alpine alluvial fan using airborne LiDAR. Natural Hazards and Earth System Sciences, 8, 323-333. doi:10.5194/nhess-8-323-2008.

Chen, R. F., Lin, C. W., Chen, Y. H., He, T. C. and Fei, L. Y. (2015): Detecting and Characterizing Active Thrust Faults and Deep-Seated Landslides in Dense Forest Areas of Southern Taiwan Using Airborne LiDAR DEM. Remote Sensing, 7, 15443-15466. doi: 10.3390/rs/71115443

CEAN, Croatian Agency for Environment and Nature (2008): Corine Land Cover Croatia, Land Use Map 1:100,000.

Dearman, W. R. (1991): Engineering Geological Mapping. Butterworth-Heinemann, $385 \mathrm{p}$.

Đomlija, P., Bočić, N. and Mihalić Arbanas, S. (2017): Identification of geomorphological units and hazardous processes in the Vinodol Valley. In: Abolmasov, B., Marjanović, M., Đurić, U. (eds.): Proceedings of $2^{\text {nd }}$ Regional Sympo- sium on Landslides in the Adriatic-Balkan Region, Faculty of Mining and Geology, University of Belgrade, 109-116.

Đomlija, P. (2018): Identifikacija i klasifikacija klizišta i erozije vizualnom interpretacijom digitalnoga modela reljefa Vinodolske udoline (Identification and classification of landslides and erosion phenomena using the visual interpretation of the Vinodol Valley Digital Elevation Model). Doctoral dissertation, University of Zagreb, Faculty of Mining, Geology and Petroleum Engineering, Zagreb, 527 p. (in Croatian - English abstract)

Đomlija, P., Bernat Gazibara, S., Arbanas, Ž. and Mihalić Arbanas, S. (2019a): Identification and mapping of soil erosion processes using the visual interpretation of LiDAR imagery. ISPRS International Journal of Geo-Information, 8, 438. doi: 10.3390/ijgi8100438

Đomlija, P., Jagodnik, V., Arbanas, Ž. and Mihalić Arbanas, S. (2019b): Landslide types identified along carbonate cliffs using LiDAR imagery - examples from the Vinodol Valley, Croatia. In: Uljarević, M., Zekan, S., Salković, S., Ibrahimović, Dž. (eds.): Proceedings of the $4^{\text {th }}$ Regional Symposium on Landslides in the Adriatic-Balkan Region, Geotechnical Society of Bosnia and Herzegovina, Sarajevo, 91-96.

Görüm, T. (2019): Landslide recognition and mapping in a mixed forest environment from airborne LiDAR data. Engineering Geology, 258, 105155. doi: 10.1016/j.enggeo. 2019.105155

Grimani, I., Šušnjar, M., Bukovac, J., Milan, A., Nikler, L., Crnolatac, I., Šikić, D. and Blašković, I. (1973): Explanatory notes for Basic Geological Map of Yugoslavia 1:100,000, Crikvenica Sheet L33-102. Geological Survey Zagreb, published by Federal Geological Institute Beograd. (in Croatian)

Guzzetti, F., Mondini, A.C., Cardinali, M., Fiorucci, F., Santangelo, M. and Chang, K.T. (2012): Landslide inventory maps: new tools for an old problem. Earth-Science Reviews, 112, 42-66. doi: 10.1016/j.earscirev.2012.02.001

Haugerud, R.A., Harding, D.J., Johnson, S.Y., Harless, J.L., Weaver, C.S. and Sherrod, B.L. (2003): High-resolution lidar topography of the Puget Lowland, Washington - A bonanza for earth science. GSA Today, 13, 4-10. doi: 10.1130/1052-5173(2003)13<0004:HLTOTP $>2.0$ CO;2

Hungr, O., Leroueil, S. and Picarelli, L. (2014): The Varnes classification of landslide types, an update. Landslides, 11, 167-194. doi: 10.1007/s10346-013-0436-y

Jež, J. (2007): Vzroki in mehanizem zemaljskega plazenja na Rebrnicah v Vipavski dolini (Reasons and mechanisms for soil sliding processes in the Rebrnice area, Vipava Valley, SW Slovenia). Geologija, 50/1, 55-63. (in Slovenian - English abstract). doi: 10.5474/geologija.2007.005

Kocjančić, M., Popit, T. and Verbovšek, T. (2019): Gravitational sliding of the carbonate megablocks in the Vipava Valley, SW Slovenia. Acta geographica Slovenica, 59(1), 7-22. doi: 10.3986/AGS.4851

Notebaert, B., Verstraeten, G., Govers, G. and Poesen, J. (2009): Qualitative and quantitative applications of LiDAR imagery in fluvial geomorphology. Earth Surface Processes and Landforms, 34, 217-231. doi: 10.1002/ esp. 1705 
Palenik, D., Matičec, D., Fuček, L., Matoš, B., Herak, M. and Vlahović, I. (2019): Geological and structural setting of the Vinodol Valley (NW Adriatic, Croatia): insights into its tectonic evolution based on structural investigations. Geologia Croatica, 72/3, 179-193. doi: 10.4154/gc.2019.13

Petschko, H., Bell, R. and Glade, T. (2016): Effectiveness of visually analyzing LiDAR DTM derivatives for earth and debris slide inventory mapping for statistical susceptibility modeling. Landslides, 13/5, 857-872. doi: 10.1007/ s10346-015-0622-1

Placer, L. (2008): Vipavski prelom (Vipava fault, Slovenia). Geologija, 51/1, 101-105. (in Slovenian - English abstract). doi: 10.5474/geologija.2008.011

Popit, T. and Košir, A. (2003): Pleistocene debris flow deposits in the Vipava Valley, SW Slovenia. In: Vlahović, I. (ed.): Abstract book $-22^{\text {nd }}$ IAS Meeting of Sedimentology, Opatija 2003, Croatian Geological Survey, Zagreb, Croatia, 161-161.

Popit, T. and Košir, A. (2010): Kvartarni paleoplazovi na Rebrnicah (Quaternary fossil landslides in the Rebrnice area). In: Košir, A., Horvat, A., Zupan Hajna, N., Otoničar, B. (eds.): Povzetki in Ekskurzije / Abstracts and field trips, $3^{\text {rd }}$ Slovenian Geological Congress, Bovec, 16-18 September 2010. ZRC SAZU, Ljubljana, 39-40. (in Slovenian)

Popit, T. and Verbovšek, T. (2013): Analysis of surface roughness in the Sveta Magdalena paleo-landslide in the Rebrnice area. RMZ - Materials and Geoenvironment, 60, 197-204.

Popit, T., Jež, J., Košir, A., Fifer Bizjak, K. and Ribičič, M. (2014): Kvartarni pobočni sediment severnega in vzhodnega roba Vipavske doline (Quaternary slope deposits in the northern and eastern part of the Vipava Valley). $4^{\text {th }}$ Slovenian geological Congress, Ankaran, 8-10 October 2014. University of Ljubljana, Faculty of Natural Sciences and Engineering, Department of Geology, Ljubljana, 98-103.

Popit, T., Jež, J. and Verbovšek, T. (2017): Mass Movements Processes of Quaternary Deposits in the Vipava Valley, SW Slovenia. In: Mikoš, M., Casagli, N., Yin, Y., Sassa, K. (eds.): Advancing Culture of Living with Landslides, Volume 4 Diversity of Landslide Forms, Springer International Publishing AG 2017, 571-580. doi: 10.1007/978-3-31953485-5 66

Prelogović, E., Blašković, I., Cvijanović, D., Skoko, D. and Aljinović, B. (1981): Seizmotektonske značajke Vinodolskog područja (Seismotectonic characteristics of the Vinodol area). Geološki vjesnik, 33, 75-93, Zagreb. (in Croatian - English abstract)

Ruszkiczay-Rüdiger, Z., Fodor, L., Horváth, E. and Telbisz, T (2009): Discrimination of fluvial, eolian and neotectonic features in a low hilly landscape: A DEM-based morphotectonic analysis in the Central Pannonian Basin, Hungary.
Geomorphology, 104, 203-217. doi:10.1016/j.geomorph. 2008.08.014.

Sarala, P., Räisänen, J., Johansson, P. and Eskola, K. O. (2015): Aerial LiDAR analysis in geomorphological mapping and geochronological determination of superficial deposits in the Sodankyla region, northern Finland. GFF, 137(4), 293303. doi: $10.1080 / 11035897.2015 .1100213$

Scaioni, M., Longoni, L., Melillo, V. and Papini, M. (2014): Remote Sensing for Landslide Investigations: An Overview of Recent Achievements and Perspectives. Remote Sensing, 6/10, 9600-9652. doi: 10.3390/rs60x000x

Selby, M. J. (1993): Hillslope materials and processes. Oxford University Press, Oxford.

Šapina, M., and Vekić, M. (2015): New Lithostratigraphic Units in the Croatian Offshore and Their Definition in the ' 'R'" Programming Language. Rudarsko-geološko-naftni zbornik (The Mining-Geology-Petroleum Engineering Bulletin), 30, 2, 13-24. doi: 10.17794/rgn.2015.2.4

Šušnjar, M., Bukovac, J., Nikler, L., Crnolatac, I., Milan, A., Šikić, D., Grimani, I., Vulić, Ž. and Blašković, I. (1970): Basic Geological Map of Yugoslavia 1:100,000, Crikvenica Sheet L33-102. Geological Survey Zagreb, published by Federal Geological Institute Beograd.

Tarolli, P. (2014): High-resolution topography for understanding Earth surface processes: Opportunities and challenges. Geomorphology, 216, 295-312. doi: 10.1016/j.geomorph. 2014.03.008

Van Den Eeckhaut, M., Poesen, J., Verstraeten, G., Vanacker, V., Nyssen, J., Moeyersons, J., van Beek, L. P. H. and Vandekerckhove L. (2007): Use of LIDAR-derived images for mapping old landslides under forest. Earth Surface Processes and Landforms, 32, 754-769. doi: 10.1002/esp.1417

Velić, J., Malvić, T., Cvetković, M. and Velić, I. (2015): Stratigraphy and petroleum geology of the Croatian part of the Adriatic Basin. Journal of Petroleum Geology, 38, 3, 281300. doi: 10.1111/jpg.12611

Verbovšek, T., Košir, A., Teran, M., Zajc, M. and Popit, T. (2017): Volume determination of the Selo landslide complex (SW Slovenia): integrating field mapping, ground penetrating radar and GIS approaches. Landslides, 14, 1265-1274. doi: 10.1007/s10346-017-0815-x

Webster, T. L., Murphy, J. B., Gosse, J. C. and Spooner, I. (2006): The application of lidar-derived digital elevation model analysis to geological mapping: an example from the Fundy Basin, Nova Scotia, Canada. Canadian Journal of Remote Sensing, 32, 2, 173-193.

Wehr, A. and Lohr, U. (1999): Airborne laser scanning - an introduction and overview. ISPRS Journal of Photogrammetry and Remote Sensing, 54(2-3), 68-82. doi: 10.1016/ S0924-2716(99)00011-8 


\title{
SAŽETAK
}

\section{O vrstama i prostornoj raspodjeli kvartarnih naslaga sastavljenih od fragmenata karbonatnih stijena u Vinodolskoj udolini, Hrvatska - nove spoznaje na temelju visinskih LiDAR podataka}

\begin{abstract}
Vinodolska udolina, smještena u sjeverozapadnome dijelu Hrvatskoga primorja, odlikuje se složenom geološkom građom i morfološkim uvjetima. Unutrašnji udolinski prostor izgrađuju flišolike naslage paleogenske starosti, a strmi bokovi udoline izgrađeni su od karbonatnih stijena kredne i paleogenske starosti. Padine izgrađene od flišolikih naslaga gotovo su u potpunosti prekrivene različitim vrstama površinskih naslaga kvartarne starosti, među kojima su obilno zastupljene površinske naslage sastavljene od fragmenata karbonatnih stijena. Tijekom prethodnih istraživanja, temeljenih na konvencionalnome terenskom geološkom kartiranju uglavnom u sjeverozapadnome i središnjemu dijelu Vinodolske udoline, ove su kvartarne naslage smatrane izravnom posljedicom tektonskoga razvoja istraživanoga područja, odnosno posljedicom pojava odrona, pa su općenito nazivane kvartarnim vapnenačkim brečama i kvartarnim naslagama odrona. Ovaj rad prikazuje šest vrsta kvartarnih naslaga sastavljenih od fragmenata karbonatnih stijena te njihovu prostornu raspodjelu na cijelome području Vinodolske udoline $\left(64,57 \mathrm{~km}^{2}\right)$, koje su identificirane i kartirane na temelju vizualne interpretacije digitalnoga modela reljefa (DMR) prostorne rezolucije 1 x $1 \mathrm{~m}$ izrađenoga od visinskih podataka prikupljenih laserskim skeniranjem iz zraka primjenom LiDAR tehnologije. Litološki materijali klasificirani su u skladu s inženjerskogeološkim principima i predstavljaju inženjerske formacije. Nove spoznaje o vrstama, oblicima, geometrijskim značajkama i hipsometrijskim položajima identificiranih sedimentnih tijela upućuju na to da su i neki ostali tipovi gravitacijskih pokreta, a ne samo odroni, imali važnu ulogu u formiranju kvartarnih naslaga sastavljenih od fragmenata karbonatnih stijena u Vinodolskoj udolini. Ovaj rad također prikazuje i mogućnosti primjene metode vizualne interpretacije DMR-a izrađenoga od visinskih podataka prikupljenih laserskim skeniranjem iz zraka primjenom LiDAR tehnologije za identifikaciju i kartiranje površinskih naslaga na područjima istraživanja obilježenima složenom geološkom građom i morfološkim uvjetima.
\end{abstract}

\section{Ključne riječi:}

kvartarne naslage, vizualna interpretacija, LiDAR DMR, fosilna klizišta, Vinodolska udolina

\section{Author's contribution}

This manuscript is written based on the results obtained through the doctoral research of the principal researcher Petra Jagodnik (Ph.D., Senior Lecturer, Engineering Geology), who performed the visual interpretation of LiDAR topographic derivatives, provided an overview of previous investigations, conducted field investigations, and performed the geomorphological interpretation of the results. Writing of the manuscript and preparation of the graphics was also performed by the principal researcher. Sanja Bernat Gazibara (Ph.D., Postdoctoral Researcher, Engineering Geology) produced the DTM from airborne LiDAR data, contributed to the visual interpretation of LiDAR topographic derivatives, geomorphological interpretation of the results, and reviewed the manuscript. Vedran Jagodnik (Ph.D., Assistant Professor, Geotechnical Engineering) conducted field investigations, soil sampling and laboratory testing, provided the analysis of the laboratory testing results and contributed to geotechnical classification of identified engineering materials. The supervisor of the doctoral thesis, Snježana Mihalić Arbanas (Ph.D., Full Professor, Engineering Geology), contributed to the interpretation of the research results, participated in field investigations, provided suggestions for the preparation of graphics and conceptualization of discussion and conclusion sections, and contributed to the reviewing of the manuscript. 